Article

\title{
The Geology of the Middle Cam Valley, Cambridgeshire, UK
}

\author{
Steve Boreham * (1) and Karolina Leszczynska \\ Department of Geography, University of Cambridge, Cambridge CB2 3EN, UK \\ * Correspondence: sb139@cam.ac.uk
}

Received: 18 April 2019; Accepted: 4 July 2019; Published: 12 July 2019

\begin{abstract}
This study offers a new understanding of the stratigraphy and context of the Pleistocene (including Elsterian and Weichselian) and Holocene deposits of the Middle Cam valley, Cambridgeshire, United Kingdom, and provides a unique and detailed view of the sediment architecture of these valley-fill and interfluve sediments. The new insights into the geology of the area, including dating, pollen analyses, and sediment architecture, are presented with reference to a series of nine cross-sections through Holocene and Pleistocene deposits, as well as Cretaceous bedrock across the region. The structural geology of the bedrock and the stratigraphic arrangement of younger deposits are used to explain the landscape evolution of the area.
\end{abstract}

Keywords: Holocene; Weichselian; Elsterian; Pleistocene; Cam valley

\section{Introduction}

This paper aims to describe the lithostratigraphy and sediment architecture of Holocene, Weichselian, and earlier Pleistocene deposits in the River Cam valley south of Cambridge, United Kingdom (UK), by adding new geological observations by the authors to archival descriptions and borehole data. Understanding the geology of the Middle Cam valley is essential for linking the geology of the Upper Cam and Lower Cam [1,2]. The Pleistocene geology and palaeoenvironments of the Cambridge district [3], and the relationship of the Cam valley deposits to the Wash fluvial network have been investigated previously [4].

The Middle Cam valley is drained by the River Cam, which runs southeast to northwest across the study area and is joined by the River Granta from the east (Figure 1). The River Rhee flows southwest to northeast across the area, and joins the River Cam north of Hauxton village. At Byron's Pool, the Bourn Brook flowing from the west also joins the Cam. The River Cam then flows north through Grantchester towards central Cambridge. Hobson's Brook, a tributary of the River Cam, is a misfit stream, which flows north from Great Shelford and occupies a valley that once held the mid-Weichselian course of the River Cam [3].

These valley-confined streams have a meandering single-thread morphology but show ample evidence for past drainage diversion and river capture. Situated south of Cambridge, the study area is characterised by low rolling hills, often with thin chalky soils overlying chalk and clay-rich bedrock. However, this simplistic description disguises a range of interesting geological features in the district. 


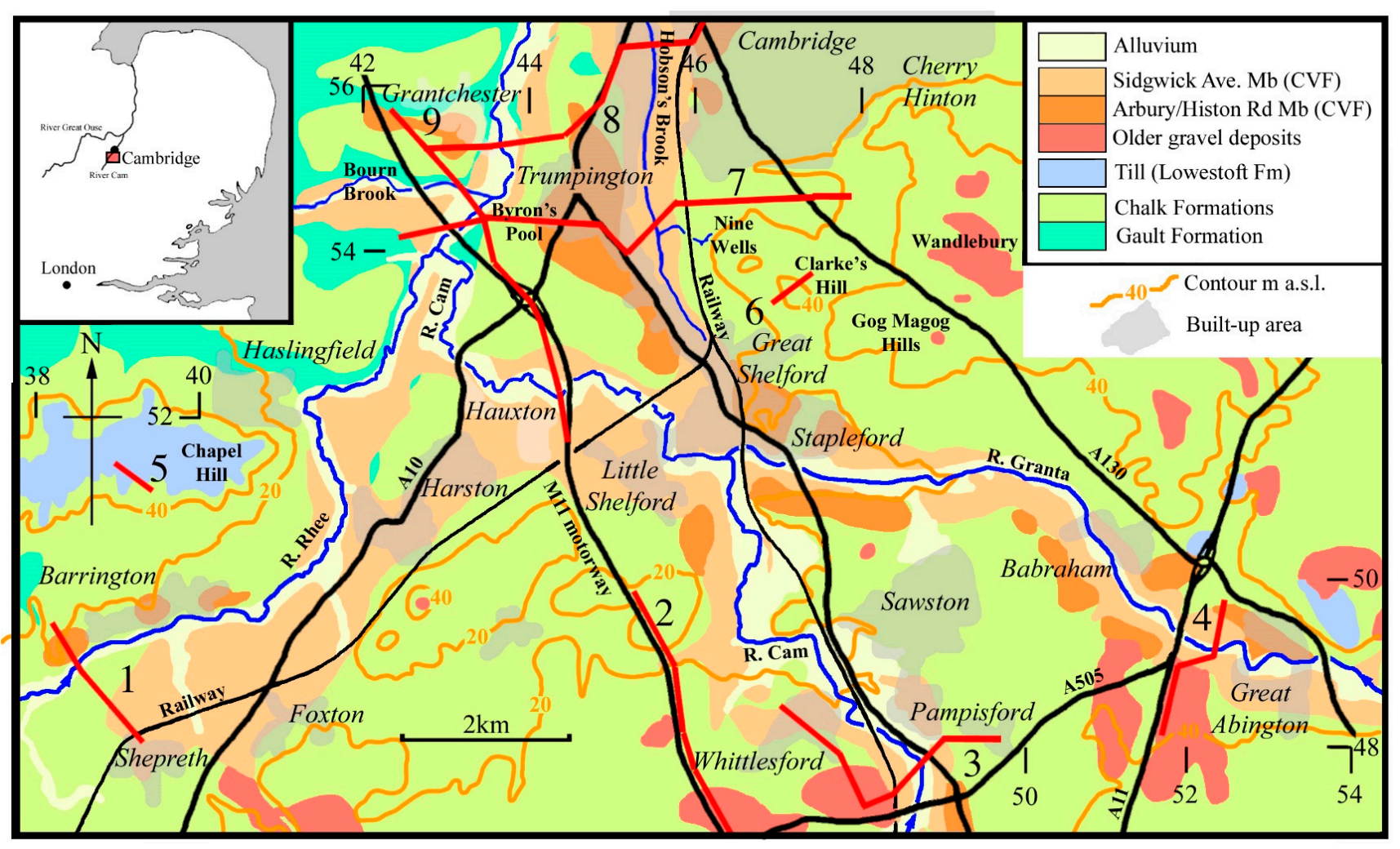

Figure 1. Map of the Middle Cam valley showing the simplified geology taken from the Saffron Walden Sheet (205), and geological sections 1-9 shown in Figures 2-10. Note that Quaternary deposits are mapped only where $>1 \mathrm{~m}$ in thickness. The Ordnance Survey grid at 2-km intervals is included for reference. Reproduced from British Geological Survey. 1981. Saffron Walden Sheet. England and Wales Sheet 205 Solid and Drift Geology. 1:50,000. British Geological Survey. 


\section{Drainage and Bedrock}

The area included in this study stretches from Grantchester, southern Cambridge, and Cherry Hinton in the north, to Babraham and Great Abington in the east, Whittlesford and Pampisford to the south, and Haslingfield, Barrington, and Shepreth to the west. The study area encompasses the Gog Magog Hills (ca. $70 \mathrm{~m}$ O.D. (Ordnance Datum)) to the east and Chapel Hill (ca. $60 \mathrm{~m}$ O.D.) to the west.

The River Cam is a tributary of the River Great Ouse, which flows for ca. $50 \mathrm{~km}$ north of Cambridge through Fenland in a largely artificial channel to enter the southern North Sea at King's Lynn on the Wash. The River Cam, River Granta, River Rhee, and the Bourn Brook together drain a ca. 1000 km² catchment of low chalky hills to the south of Cambridge.

The Rivers Cam and Granta appear to be dip-slope streams draining northwest from the degraded Chalk escarpment of the southern Cambridgeshire/Essex border. However, the River Cam also follows the course of an Elsterian glacial 'tunnel valley' [1] that can be traced for almost $30 \mathrm{~km}$ to the south. Tunnel valleys are steep-sided channel forms originally eroded by subglacial meltwater near the margins of terrestrial ice sheets. In contrast, the River Rhee is a strike-aligned stream draining northeast along the foot of the degraded chalk escarpment, and the Bourn Brook drains eastwards from a large plateau underlain by Elsterian glacial till.

The bedrock geology of the Middle Cam valley shows a general dip of the Cretaceous strata towards the southeast [5]. The bedrock in the Middle Cam valley comprises the Cretaceous Gault Formation (mudstone) overlain by the soft limestone of the West Melbury (Marly) Chalk Formation, the Zig Zag Chalk Formation, the Holywell Nodular Chalk Formation, and the New Pit Chalk Formation [6], which are equivalent to the Gault Clay, Lower Chalk and Middle Chalk of the former classification (see Figure 1) [7,8]. Between Hauxton and Cambridge, the River Cam is broadly aligned with the junction between the West Melbury (Marly) Chalk Formation and the Gault Formation.

\section{Pleistocene and Holocene Lithostratigraphy and Depositional History}

A lithostratigraphic scheme for the Pleistocene deposits in the valley of the River Cam has been developed [9]. Glacial till (boulder clay) has been identified as one of the oldest Pleistocene deposits of the Cambridge District [5] and is attributed to the Barrington Works Member of the glaciogenic Elsterian Lowestoft Formation (LF). Elsterian glaciolacustrine sediments occupying deeply incised buried channels were correlated with the Wicken Bonhunt Member, and glacial gravels filling 'tunnel valleys' were ascribed to the Observatory Member [1].

The 'valley gravels' of the Cam system were separated based on elevation into numbered terraces (third, second, first) using a morphostratigraphic paradigm $[10,11]$. These fluviogenic deposits are placed in the Cam Valley Formation (CVF). Other gravel deposits (of Elsterian age and possibly older) are found in the capping hills and interfluves throughout the area [12].

The oldest course of the River Cam system in the study area is shown by the fragmentary (uppermost) third terrace correlated here with the Impington Village Member, Histon Road Member, and the Arbury Member of the Cam Valley Formation. It appears to span the Saalian, Eemian, and early Weichselian (MIS 7-MIS 5a) interval. The mid-Weichselian (MIS 3-4) course of the River Cam (second terrace-Sidgwick Avenue Member) formed the present Hobson's Brook valley, taking water from the Granta, Cam, and Rhee to the east of the modern course [13]. The (lowermost) first terrace of the River Cam in Cambridge appears to be late-Weichselian (MIS 2) in age [14], but in the study area, it is poorly developed and often hidden beneath the Holocene floodplain. It is identified as the Barnwell Station Member of the Cam Valley Formation.

In late-Weichselian times (MIS 2), the River Cam avulsed to the west of Trumpington, presumably into a pre-existing strike-aligned tributary valley associated with the Bourn Brook, and incised a channel form that later became the inherited course of the Holocene River Cam. Basal gravels beneath the Holocene deposits within the incised channel form are identified as the Midsummer Common Member of the Cam Valley Formation. The Holocene deposits of the Middle Cam valley are represented 
by floodplain alluvium and peat that are placed in the Jesus Green Member. It is worth noting that in the Lower Cam at the edge of Fenland, the Holocene peat was assigned to the Fenland Formation [2].

\section{Methods}

\subsection{Field Methods}

Data acquisition was from borehole and trial pit records, and from visits to building developments, sewer repairs, gravel pits, and temporary excavations. Boreholes were undertaken to investigate sites where satisfactory exposures and previous data were not available. These were mostly sunk using hand augers, although a motorized power auger was used where ground conditions were difficult. Geological exposures and boreholes were logged and described, where possible recording both the geometry of sediments, including characteristics such as lithology, thickness, colour, contact with adjacent units, fossil content, and sedimentary structures. Where possible, lithofacies models were applied to interpret fluvial sediments, which are characterised by a wide range of channel morphologies, particle size distributions, sedimentary structures, bedforms, and lithological geometries at a variety of scales $[15,16]$.

\subsection{Laboratory Methods}

\subsubsection{Clast Lithological Analysis}

Bulk sediment samples taken for Clast Lithological Analysis usually weighed at least $5 \mathrm{~kg}$, although the sample of cobbles from Clark's Hill was much larger. Samples were dissociated using $4 \%$ $w / v$ sodium pyrophosphate solution and washed through a stack of steel sieves with mesh sizes of $32 \mathrm{~mm}, 16 \mathrm{~mm}, 11.2 \mathrm{~mm}$, and $8 \mathrm{~mm}$. The clasts retained in each sieve were carefully washed and dried. Pebble counting was undertaken using a magnifying lens and low-power stereo microscope. Critical determinations were carried out using fresh faces obtained by splitting pebbles. Identifications were routinely checked using a small reference collection. A minimum count of 300 pebbles for each sample was attempted.

\subsubsection{Pollen Analysis}

Small sediment samples for pollen analysis were prepared using the standard method of the Geography Science Laboratories, Department of Geography, University of Cambridge [17]. Sediments were sub-sampled with a $1-\mathrm{cm}^{3}$ brass volumetric sampler and treated with a succession of acids and alkalis, including hot $60 \%$ hydrofluoric acid to remove carbonates, humic acids, and silicate minerals. The acetolysed residues were stained with aqueous safranin and mounted on microscope slides using silicone fluid. Prepared pollen slides were counted using a high-power $(\times 400)$ binocular microscope, and pollen grains were identified using a reference collection housed at the Department of Geography, University of Cambridge, and pollen atlases and keys [18,19]. A minimum count of 300 pollen grains for each sample was attempted.

\subsubsection{Plant Macrofossil Analysis}

Bulk sediment samples (1-5 kg) for Plant Macrofossil Analysis were dissociated using $4 \% w / v$ sodium pyrophosphate solution and washed through sieves with mesh sizes of $2 \mathrm{~mm}, 1 \mathrm{~mm}, 500 \mu \mathrm{m}$, and $250 \mu \mathrm{m}$. Fragments of all identifiable macrofossils such as leaves, seeds, fruits, achenes, capsules, and nuts were carefully picked using a fine paint brush or forceps using a magnifying lens and low-power stereo microscope. Plant macrofossils were identified by comparison with modern taxa using a reference collection housed at the Department of Geography, University of Cambridge. 


\subsubsection{Mollusc Analysis}

Bulk sediment samples (1-5 kg) for mollusc analysis were disaggregated in water before being washed through sieves with mesh sizes of $2 \mathrm{~mm}, 1 \mathrm{~mm}, 500 \mu \mathrm{m}$, and $250 \mu \mathrm{m}$. The residues were air dried and examined under a low-power binocular microscope. All the shells and shell apices were picked from the residues and identified as far as possible [20].

\subsubsection{Beetle Analysis}

Bulk sediment samples (ca. $5 \mathrm{~kg}$ ) for beetle analysis were disaggregated in water before being washed through sieves with mesh sizes of $2 \mathrm{~mm}, 1 \mathrm{~mm}, 500 \mu \mathrm{m}$, and $250 \mu \mathrm{m}$. For some samples, a floatation technique using liquid paraffin was also employed. The sieved residues were examined under a low-power binocular microscope. Most of the beetles were identified to species level as far as possible, which follow [21].

\subsubsection{Optically Stimulated Luminescence Dating}

Samples for optically stimulated luminescence (OSL) dating were protected from sunlight during sampling or transport to the laboratory. In the laboratory, the outside layers of the sediment blocks were removed in darkroom conditions. The concentration of potassium, thorium, and uranium, the main contributors of environmental radiation to sedimentary quartz, were determined using an ICP (Inductively Coupled Plasma) analyser. Elemental concentrations were converted to give dose rates, and added to the dose contribution from cosmic sources, and attenuated to allow for grain size and palaeomoisture content.

The samples were prepared under darkroom conditions to extract and clean quartz with a size range of 90-125 $\mu \mathrm{m}$ [22]. OSL measurements were carried out using a Risø reader fitted with a filtered $150-\mathrm{W}$ halogen lamp. The samples were dosed with a calibrated ${ }^{90}$ strontium beta source. The samples were pre-heated to remove the unstable signal generated by laboratory irradiations, and were found to have no pre-heat dependence.

Multiple palaeodose $\left(D_{e}\right)$ determinations were made to determine whether the samples had been fully zeroed (bleached) at deposition. The palaeodose for the samples showed very weak or no partial bleaching. The calculated age was quoted in absolute years from the present day with one-sigma confidence intervals, incorporating systematic uncertainties within the dosimetry data, uncertainties with the palaeomoisture content, and errors associated with the mean palaeodose $\left(D_{e}\right)$ determination.

\subsubsection{Amino Acid Racemization Dating}

Samples for amino acid racemization dating (AAR) dating were carefully selected and prepared using the method in Section 4.2.4 above. Well-preserved fossil mollusc shells from taxa known to epimerize at a 'slow' rate were selected for amino acid dating. Where possible, at each site, four specimens of a single taxon were chosen. The fossil mollusc shells were prepared to produce acid hydrolysates of the preserved amino acids. Then, cation exchange chemistry in a high precision liquid chromatograph was used to measure the ratio of D-alloisoleucine to L-isoleucine [23]. Where possible, multiple analyses were made on each shell. The chromatograms produced by these analyses were carefully examined, and the mean ratio of D-alloisoleucine to L-isoleucine $(\mathrm{D} / \mathrm{L})$ was calculated. Age determination was accomplished using a correlation between the marine oxygen isotope stages and the D/L ratios from southern England [9].

\subsubsection{Radiocarbon Dating}

The sample of sediment from Hauxton Meadow was sent for bulk radiocarbon dating to the Waikato Radiocarbon Laboratory in New Zealand. At the laboratory, the sample was prepared by washing in hydrochloric acid and sodium hydroxide. Then, the insoluble fraction was collected 
for dating. The radiocarbon age determination (WK-21756) was based on the Libby half-life of $5568 \pm 30$ years with an applied correction for isotopic fractionation [24].

\section{Cross-Sections and Descriptions of the Middle Cam Valley}

In the next sections, the lithology and the stratigraphic context of the deposits filling the valley and capping the interfluves of the Middle Cam are presented. Nine geological cross-sections cut through Pleistocene and Holocene deposits are shown located within various parts of the valley. In addition, research from nine sites is described in more detail. The information gathered in these discrete locations allows us to investigate the major geological features and reconstruct the evolution of the landscape in the research area.

\subsection{Geological Section 1-Barrington Village to Shepreth}

This ca. 2.5-km long section (Figure 2) is aligned roughly northwest-southeast from Barrington village, across the River Rhee floodplain to Shepreth. The dip of the bedrock towards the southeast can be seen in this section, with the West Melbury Chalk Formation overlying the Gault Formation.

At Barrington village in the location of a now disused quarry called Cardo's Pit, a channel-form ca. 3-m deep incision into the bedrock is filled by a thin basal gravel overlain by ca. $5 \mathrm{~m}$ of silt (Histon Road Member CVF). The deposits here appear to represent the course of the River Rhee dating from the early-Weichselian and older and are described in Section 5.2 below.

To the southeast, the River Rhee floodplain is quite narrow and characterised by alluvial silty clay overlying peat (Jesus Green Member CVF) and gravel. The floodplain is underlain by a channel-form ca. 6-m deep incised into the Gault Clay Formation, which was filled by ca. $1 \mathrm{~m}$ of late-Weichselian basal sand and gravel (Midsummer Common Member CVF) and ca. $4 \mathrm{~m}$ of peat (Jesus Green Member $\mathrm{CVF}$ ). To the southeast, a broad terrace at Shepreth is underlain by ca. $1.5 \mathrm{~m}$ of sand and gravel (second terrace deposits-Sidgwick Avenue Member CVF) that represents the mid-Weichselian course of the River Rhee.

\subsection{Cardo's Pit Deposits, Barrington Village}

The first fossiliferous deposits were described from Barrington from a pit east of the village in 1879 [25]. Sections of similar deposits were subsequently exposed in coprolite workings west of Barrington village at the precursor of Cardo's Pit [26]. The silty clay of the 'Barrington Beds' was described as rich in mammalian remains, with small pieces of bone occurring throughout. However, it was the underlying gravel that yielded numerous and well-preserved bones. A section from Cardo's Pit recorded $1 \mathrm{~m}$ of clayey gravel that was rich in molluscs and mammal remains beneath $5 \mathrm{~m}$ of silty clay [27].

\subsubsection{Pollen}

Pollen analyses by SB of silt scraped from two hippopotamus teeth and a rhinoceros jaw from the Sedgwick Museum collection were characterised by high frequencies (ca. 90\%) of grass and herbs [28]. Tree and shrub pollen was represented by oak (Quercus), pine (Pinus), hazel (Corylus), and willow (Salix), with several other taxa including maple (Acer), alder (Alnus), and elm (Ulmus). A similar assemblage was reported from silt that was also scraped from a hippopotamus tooth [29]. SB also undertook pollen analyses on a number of specimens of silt from the Sedgwick Museum collection and from a borehole sunk by the author. These show pollen assemblages dominated by grass and herbs. Tree and shrub pollen was represented by low frequencies of oak (Quercus), pine (Pinus), hazel (Corylus), willow (Salix), birch (Betula), alder (Alnus), and juniper (Juniperus). This is in broad agreement with previous analyses [28], although some of the temperate elements of mixed oak woodland that were identified, such as maple (Acer) and elm (Ulmus), were missing. 


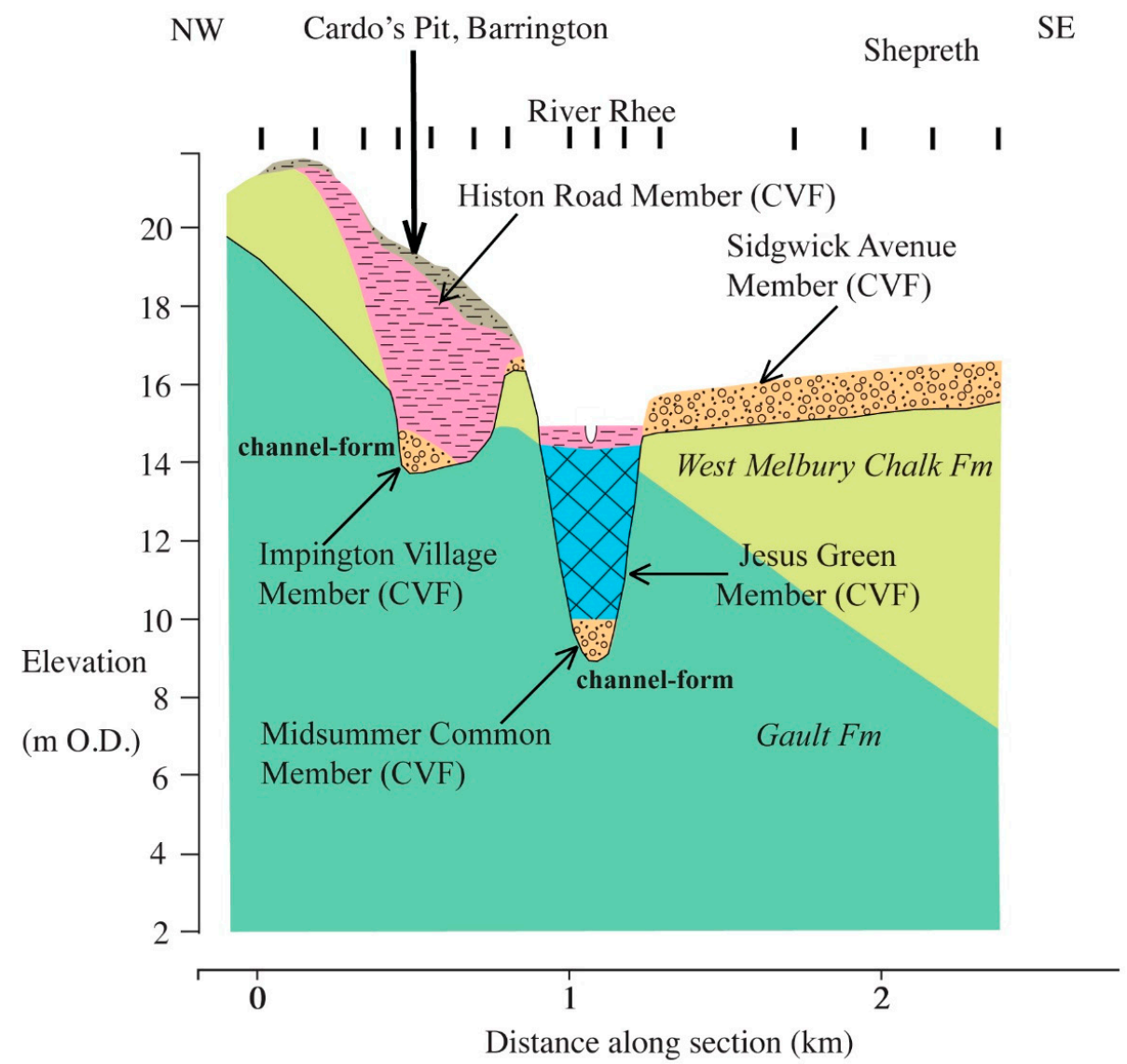

Lithology Key (Figures 2-5 \& 8-10)

Pleistocene \& Holocene Bedrock

$\begin{array}{lll}\square & \text { Sandy clay } & \text { Chalk Formations (limestone) } \\ \square & \text { Silty clay } & \text { Gault Formation (mudstone) }\end{array}$

Figure 2. Geological Section 1 across the Rhee valley from Cardo's Pit, Barrington to Shepreth constructed from borehole records. The locations of the boreholes are shown by tick marks above the section. A key to the lithological symbols used in Figures $2-5$ and $8-10$ is included. 
These assemblages represent an open grassland floodplain environment with some local carr vegetation and shrubby mixed oak woodland at some distance from the river on higher ground. There are relatively few temperate elements in the flora, suggesting generally cool climatic conditions, which is consistent with the early part of an interglacial (substages I to II), and most likely the Eemian (MIS 5e) [28].

\subsubsection{Molluscs}

Various molluscs recovered from the silty clay suggest Scandinavian or continental conditions [25,26]. Washing large quantities of the Cardo's Pit silts yielded a similar mollusc fauna, with most taxa indicating a slow-moving, well-oxygenated river with some fringing vegetation, marshland, and riparian habitats, and a few snails of scrub and woodland habitats [30,31].

A collection of molluscs made by C. E. Gray from silts within the very basal part of the Cardo's Pit gravels yielded pristine specimens of Corbicula, together with other aquatic taxa including Bithynia tentaculata. The presence of this taxon has been taken to indicate a MIS 7 age at other sites [32,33].

\subsubsection{Vertebrates}

A large collection of Barrington vertebrate material in the Sedgwick Museum, Cambridge, and smaller collections in the British Museum (Natural History) and the Geological Survey Museum, London yielded a diverse assemblage reflecting the variety of available habitats in the vicinity of the river [28].

Temperate woodland habitats are indicated by the presence of Dama dama (fallow deer), Cervus elephas (red deer), Meles meles (badger), and Palaeoloxodon antiquus (straight-tusked elephant). Conversely, taxa such as Crocuta crocuta (spotted hyena), Panthera leo (lion), Bos primigenius (aurochs), Bison priscus (bison), and Megaloceros giganteus (giant deer) are believed to favour grassland areas. Evidence of riparian and aquatic habitats is provided by the presence of Hippopotamus amphibius (hippopotamus) and the water vole Arvicola terrestris. This 'hippopotamus fauna' without Corbicula is associated with the Eemian Stage [34-36].

\subsubsection{Dating}

Two distinct collections of shells were available from the Sedgwick Museum for amino acid dating (analyzed by C.P. Hart). Amino acid racemization analyses for Trichia spp. shells associated with hippopotamus gave $\mathrm{D} / \mathrm{L}$ ratios of $0.082,0.138,0.154$, and 0.203 . The lowest of these ratios equates to an Early Weichselian age (MIS 5a/c), using the correlation between the marine oxygen isotope stages and the D/L ratios from southern England [9], whilst the others indicate dates in the later (MIS 6/7) and middle (MIS 7/8) parts of the Saalian interval. This mixed amino acid signal means that a minimum age estimate for the last phase of deposition based on the lowest $\mathrm{D} / \mathrm{L}$ ratios is the Weichselian (MIS $5 \mathrm{a} / \mathrm{c}$ ). This is quite close to the Eemian (MIS 5e) age suggested by most of the floral and faunal assemblages, despite the apparent absence of Eemian-age shells. In addition, the apparent age distribution of these well-preserved shells suggests some reworking of older Saalian material from nearby deposits.

Amino acid racemization analyses for Bithynia tentaculata shells from the C. E. Gray collection associated with the very basal beds containing Corbicula gave $\mathrm{D} / \mathrm{L}$ ratios of $0.173,0.208$, and 0.233 . These equate to ages in the later part (MIS 7), in the middle (MIS 8), and in the early part (MIS 8/9) of the Saalian complex. This mixed amino acid signal means that a minimum age estimate for the last phase of deposition based on the lowest $\mathrm{D} / \mathrm{L}$ ratios is within the later part of the Saalian complex (MIS 7). Again, there appears to be a significant amount of mixing or reworking in these deposits.

The implication of these two sets of amino acid ratios is that in Barrington, there is a very basal deposit of late Saalian age incorporating earlier reworked material, which was overlain by the Eemian and Early Weichselian deposits, themselves containing significant mixed or reworked elements. 


\subsubsection{Interpretation}

The basal bone bearing gravels of the Barrington Beds are remarkably similar to the interglacial organic sandy silty clay or 'diamicton' described from Woolpack Farm in the Ouse valley [37,38]. This material appears to have been laid down under low-energy fluvial conditions during the warmest part of the interglacial period, and has probably been disturbed by large mammals, thus incorporating gravel, shells, and bones into the deposit. The overlying silty clay unit was presumably deposited as in-channel or overbank fines, although the climate at this time may have been cooler.

Although there has been debate about the stratigraphic position of the Barrington Beds, it is clear that most authors believe they represent the Eemian (MIS 5e) followed by an episode of cooler climatic conditions (MIS 5a-d) [31,39]. Evidence from amino acid racemization analyses suggest that locally, there is a basal Corbicula-bearing deposit dating from the end of the Saalian complex (MIS 7), overlain by Eemian (MIS 5e) and Early Weichselian deposits. All of these deposits appear to contain significant quantities of reworked material.

\subsection{Geological Section 2-Little Shelford to Whittlesford}

This 5.5-km long section (Figure 3) is aligned roughly northwest-southeast along the line of the M11 motorway from Clunch Pit Hill, Little Shelford across a minor tributary of the River Cam towards Whittlesford village. The section shows the incised nature of the chalk on the interfluve between the rivers Cam and Rhee, which ascends from ca. 20-m O.D. near Little Shelford to ca. 38 m O.D. near Hill Farm, Whittlesford.

At Clunch Pit Hill, Little Shelford, a small valley, contains a thin basal gravel overlain by ca. $1 \mathrm{~m}$ of silty clay and ca. $1 \mathrm{~m}$ of sandy silt. These valley deposits do not appear on the BGS geology map (British Geological Survey Sheet 205, 2003) and are difficult to interpret. To the south, a more deeply incised valley contains gravel and sand that was thought to be second terrace deposits, (Sidgwick Avenue Member (CVF)), and also some thin gravel, silt, and sandy silt pockets of uncertain origin on the valley sides. A chalk ridge at ca. $29 \mathrm{~m}$ O.D. at Stanmoor Hall is also capped by sandy silt. It appears that many of these thin deposits are the incised and degraded remnants of a once more extensive body of sediment.

To the southeast at Hill Farm, Whittlesford, an east-west trending ridge, is underlain by a channel-form ca. $8 \mathrm{~m}$ deep that is filled by a thin basal gravel and overlain by ca. $4 \mathrm{~m}$ of diamicton (Barrington Works Member LF) and ca. $12 \mathrm{~m}$ of silt (Wicken Bonhunt Member LF), both of which are overlain by ca. $3 \mathrm{~m}$ of sand and gravel (Observatory Gravel LF). This complex of Elsterian glaciogenic sediments appears to represent the infilling of a 'tunnel valley'.

\subsubsection{Interpretation}

The M11 motorway glaciogenic deposits at Hill Farm reveal a 'tunnel valley' incised into the chalk bedrock, with a base at ca. $23 \mathrm{~m}$ OD. This feature should be compared with the 'tunnel valleys' described at Whittlesford Station (see Section 5.5; see below) to the south, which it resembles in microcosm. The channel form here is in-filled by glaciolacustrine silt (Wicken Bonhunt Member LF) and incised by coarse gravel (Observatory Member LF). However, correlation is problematic, because Hill Farm is ca. $2 \mathrm{~km}$ west of Whittlesford Station, and apparently separated from it by a bedrock high. The arrangement of deposits is clearly complex and resembles the eroded 'roots' of a 'tunnel-valley' system. 


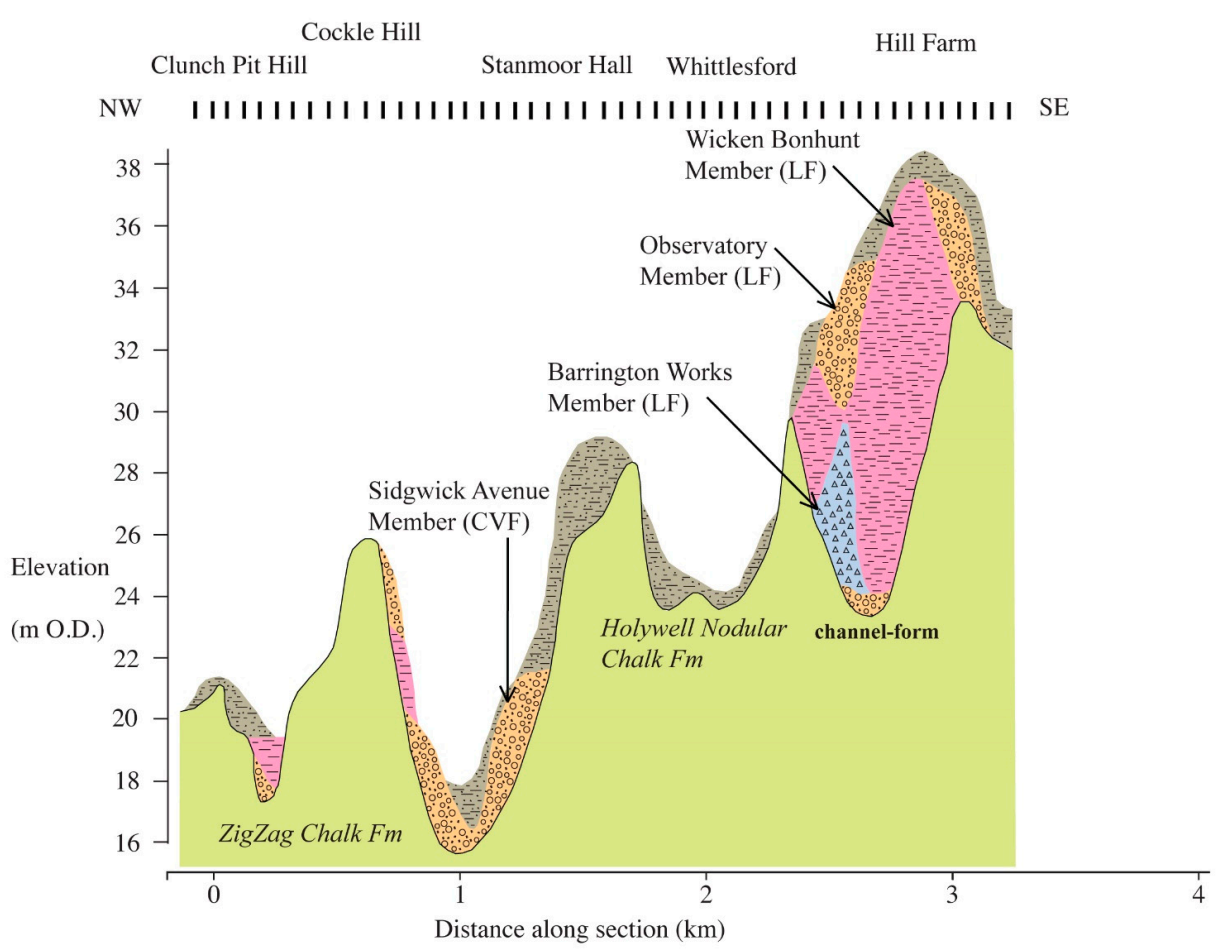

Figure 3. Geological Section 2 along the line of the M11 motorway (Clunch Pit Hill, Little Shelford to Hill Farm, Whittlesford) constructed from borehole records.

\subsection{Geological Section 3-Whittlesford to Pampisford}

This 4.5-km long section (Figure 4) is aligned firstly northwest-southeast from Whittlesford village to Whittlesford Station, and then roughly southwest-northeast across the River Cam floodplain to Pampisford village.

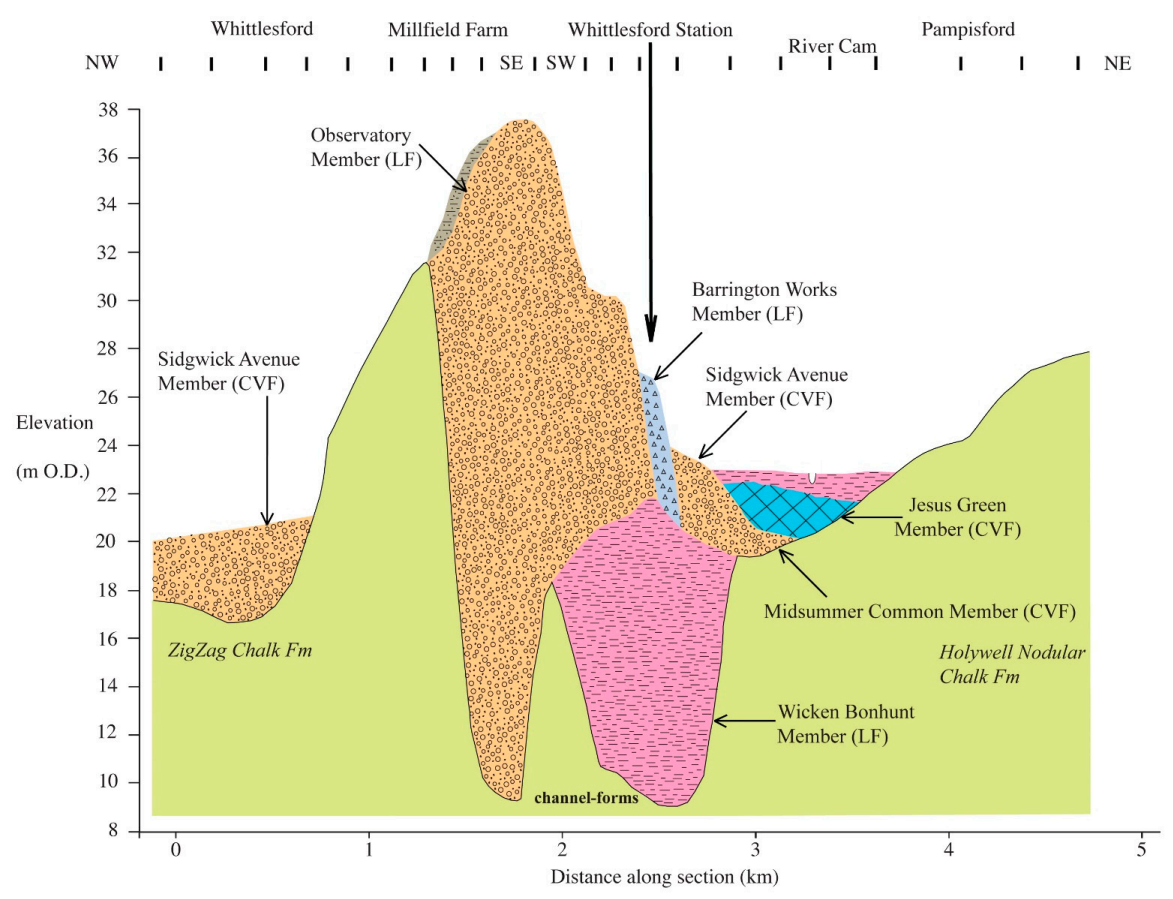

Figure 4. Geological Section 3 through Whittlesford Station and the Cam valley constructed from borehole records. 
Whittlesford village is underlain by ca. $3 \mathrm{~m}$ of sand and gravel (second terrace deposits-Sidgwick Avenue Member CVF) that represent the mid-Weichselian course of the River Cam. However, the west-east trending ridge at Millfield Farm is underlain by a channel form ca. $22 \mathrm{~m}$ deep, filled by ca. $30 \mathrm{~m}$ of gravel and sand (Observatory Member LF). Adjacent to this at Whittlesford Station, a second channel form ca. $10 \mathrm{~m}$ deep is filled by ca. $13 \mathrm{~m}$ of silt (Wicken Bonhunt Member LF) and overlain by gravel of the Observatory Member (LF), diamicton (Barrington Works Member LF). It is incised by the channel form beneath the River Cam floodplain, which is filled by the gravel and sand of the Cam Valley Formation. This complex of Elsterian age deposits in-fill two 'tunnel valleys' that may correlate with a similar feature described from Hill Farm, Whittlesford, (see Section 5.3.1 and Figure 3).

At Pampisford, the River Cam floodplain is quite broad and characterised by alluvial silty clay (Jesus Green Member CVF) overlying peat and gravel. The floodplain is underlain by a channel form ca. $4 \mathrm{~m}$ deep filled by ca. $3 \mathrm{~m}$ of mid-Weichselian sand and gravel (second terrace deposits-Sidgwick Avenue Member CVF) and late-Weichselian basal sand and gravel (Midsummer Common Member CVF) and ca. $2 \mathrm{~m}$ of peat (Jesus Green Member CVF).

\subsection{Whittlesford Station Deposits}

Several pits and boreholes in the area around Whittlesford Station have over time provided access to a wide variety of Elsterian glaciogenic deposits [40]. These include finely laminated glaciolacustrine silts of the Wicken Bonhunt Member (LF), coarse gravel belonging to the Observatory Member (LF), and chalky diamicton belonging to the Barrington Works Member. These are closely juxtaposed with each other in the vicinity of Whittlesford Station, and are incised by much later mid-Weichselian river terrace gravels of the Sidgwick Avenue Member (CVF), which in turn are overlain by Holocene deposits (Jesus Green Member-CVF) of the Cam floodplain.

Interpretation

The Whittlesford Station glaciogenic deposits together with those underlying the Millfield Farm ridge in-fill two separate 'tunnel-valleys' incised into the chalk bedrock, with bases at ca. $9 \mathrm{~m}$ O.D. These features are very similar to those described from a cross-section of the Upper Cam valley at Ickleton ca. $5 \mathrm{~km}$ to the south [1]. At Ickleton the channel form in-filled by glaciolacustrine silt (Wicken Bonhunt Member LF) occurs to the west, and the channel form in-filled by coarse gravel (Observatory Member LF) takes an easterly course. At Whittlesford Station, the situation is reversed, with the silt-filled channel to the east, and the younger gravel-filled channel to the west. This suggests that in the vicinity of Duxford village, the two 'tunnel valleys' cross each other. Certainly, a remnant of the silt-filled 'tunnel valley' occurs to the west at Hill Farm, Whittlesford (see Section 5.3.1 above). The route of these 'tunnel valleys' to the north is not entirely clear, although they are thought to correlate and align with a similar feature known from the Traveller's Rest Pit and a cutting for the A14 road in Northwest Cambridge [3].

\subsection{Geological Section 4-Great Abington}

This 2.7-km long section (Figure 5) is aligned roughly southwest-northeast from North Road, Great Abington, through Lagden's Grove, Granta Park, and Abington Hall, and across the floodplain of the River Granta.

At North Road, Great Abington, sandy silt overlying bedrock chalk mantles the valley side and fills a small dry valley that also contains thin gravel deposits of uncertain origin. At Lagden's Grove, ca. $4 \mathrm{~m}$ of silty clay (Histon Road Member CVF) is overlain by ca. $4 \mathrm{~m}$ of sand and gravel (third terrace deposits Arbury Member CVF) on the valley side. At Abington Hall, ca. $4 \mathrm{~m}$ of silty clay (Histon Road Member CVF) rests on thin gravel in a channel form, and is deeply incised by ca. $4 \mathrm{~m}$ gravel of the second terrace (Sidgwick Avenue Member CVF) at Granta Park. The Abington Hall sequence, which appear to be Eemian deposits of the River Granta, are described in Section 5.7 below. 


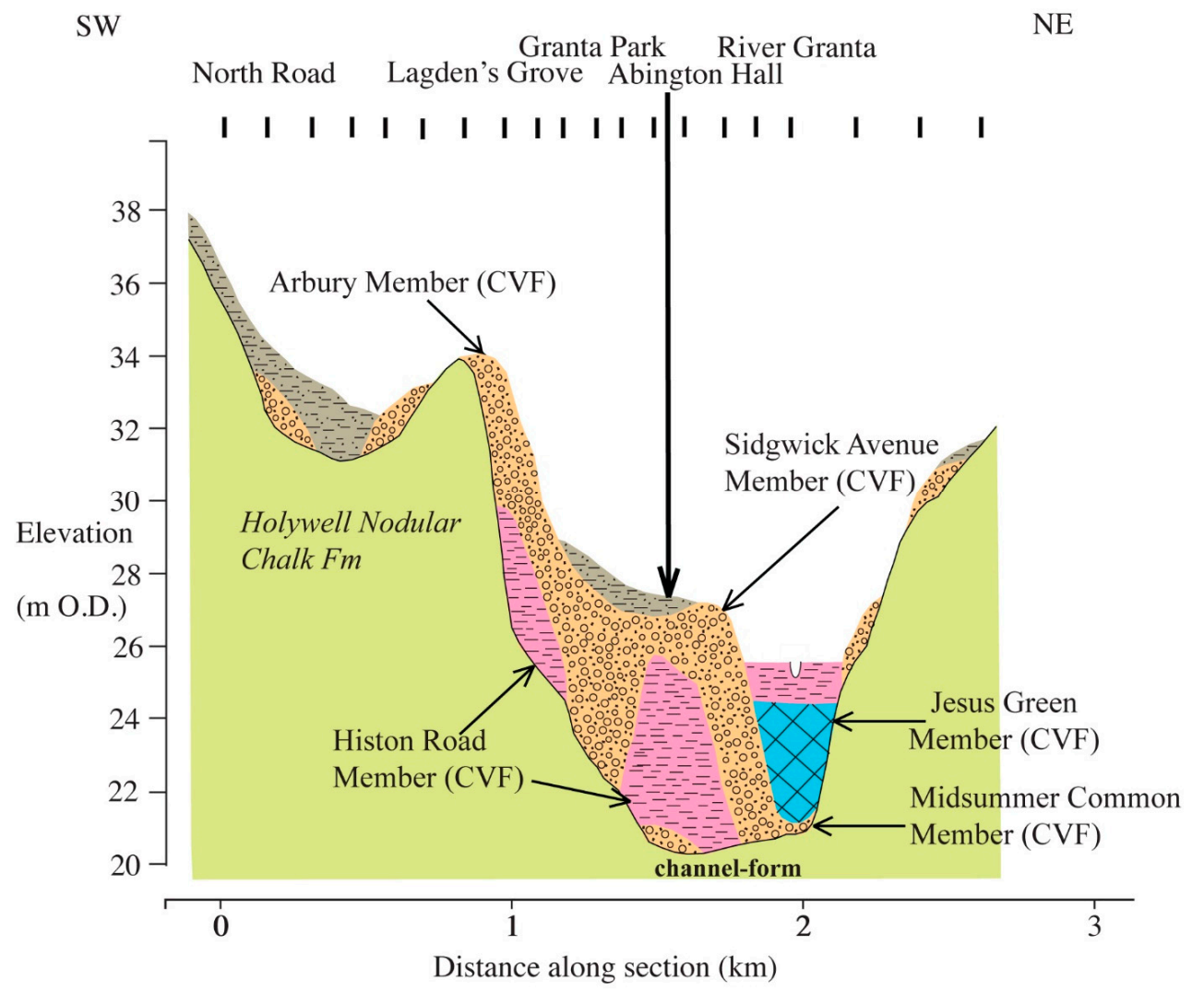

Figure 5. Geological Section 4 through Abington Hall and the Granta valley constructed from borehole records.

At Abington Hall, the River Cam floodplain is quite narrow and characterised by alluvial silty clay overlying peat (Jesus Green Member CVF) and gravel. The floodplain is underlain by a channel form ca. $4 \mathrm{~m}$ deep incised into the chalk bedrock and the adjacent terrace deposits. It is filled by ca. $2 \mathrm{~m}$ of late-Weichselian basal sand and gravel (Midsummer Common Member CVF) and ca. $3 \mathrm{~m}$ of peat (Jesus Green Member CVF). Thin gravel spreads on the northeast side of the valley represent remnants of both second and third terrace deposits.

\subsection{Abington Hall Deposits}

In 1998, the archaeological trenches at the Granta Park and Abington Hall revealed organic silts beneath the gravel adjacent to the River Rhee floodplain. SB sunk a borehole through these deposits that proved $3.5 \mathrm{~m}$ of silty clay resting on gravel. The silty clay could be traced for at least $100 \mathrm{~m}$ to the east, and excavations nearby showed $4 \mathrm{~m}$ of silty clay overlying gravel.

\subsubsection{Pollen}

SB carried out a pollen analysis of samples from the sequence of organic silty clay. The basal part of the sequence $(725 \mathrm{~cm}$ and $615 \mathrm{~cm}$ ) had a pollen assemblage dominated Poaceae (grass) (ca. $34 \%$ ) and various herbs (ca. 35\%), with birch (Betula) (ca. 15\%) and pine (Pinus) (ca. 6\%). However, at $525 \mathrm{~cm}$, there was a peak of birch (Betula) (ca. 27\%), an increasing amount of pine (Pinus) (ca. 37\%), and the first appearance of oak (Quercus), elm (Ulmus), and hazel (Corylus).

At $445 \mathrm{~cm}$ and $430 \mathrm{~cm}$, the pollen assemblage showed declining frequencies of birch (Betula), with high proportions (ca. 63\%) of pine (Pinus). At the top of the sequence $(430 \mathrm{~cm})$, mixed oak woodland components become more established, with oak (Quercus) (ca. 7\%) and elm (Ulmus) (ca. 3\%). This sequence is interpreted as recording a vegetational succession from an open grassland habitat with birch and pine scrub to closed canopy woodland, within a fluvial environment. Such a change in 
the vegetation seems consistent with climatic warming at the beginning of an interglacial (substages I to II).

\subsubsection{Plant Macrofossils}

The plant remains recovered from a sample at $400-420 \mathrm{~cm}$ were analysed by C. Turner. There was a relatively diverse aquatic flora, including spiny naiad (Najas marina), water milfoil (Myriophyllum sp.), and water plantain (Alisma plantago-aquatica), which are indicative of deposition in a still, or a slowly moving pond or backwater in temperate conditions. The remains of terrestrial herbs including the fat-hen family (Chenopodiaceae), plantain (Plantago sp.), and buttercup (Ranunculus sp.) were also found. Arboreal taxa were represented by a leaf of juniper (Juniperus), a fruit stone of plum (Prunus), and parts of willow (Salix) and birch (Betula).

The assemblage indicates a range of environments ranging from shallow open water, exposed mud, emergent marginal vegetation, and riparian herbs. In addition, there may have been scrub of juniper, birch, and willow nearby. There is no direct evidence for the mixed oak woodland or pine shown by the pollen from this part of the sequence, although this may be due to the plant macrofossils recording the local, rather than catchment vegetation.

\subsubsection{Molluscs}

Three bulk samples of sediment from Abington Hall were analysed for molluscs by R. C. Preece. The sample at 400-420 cm contained a limited predominantly aquatic fauna, including Bithynia sp. and Valvata cristata, which were both indicative of fluvial sedimentation in warm conditions. The sample at 500-540 cm contained no warm elements and was dominated by Pisidium spp. and Valvata piscinalis, indicating fluvial sedimentation. The few terrestrial molluscs present in this sample are suggestive of grassland environments. The sample from $300 \mathrm{~cm}$ was also dominated by aquatic taxa, and included Planorbis obtusale and Anisus leucostoma, which are often associated with stagnant floodplain pools. Thermophilous taxa were also absent from this sample.

\subsubsection{Beetles}

The beetle remains recovered from a sample at 400-420 $\mathrm{cm}$ were analysed by A. Dixon. The dung beetles Valgus hemipterus and Onthophagus sp. were taken to indicate temperatures that were perhaps 3-4 ${ }^{\circ} \mathrm{C}$ higher than the present, and notably, $V$. hemipterus is known from early Eemian (MIS 5e) deposits in Britain [41]. Still or slow-flowing aquatic environments are indicated by the aquatic weevil Bagous, and the reed beetle Donacia semicuprea is found on reed sweet-grass (Glyceria maxima). Dry, open grassland is suggested by the ground beetle Calathus sp., and mature deciduous woodland is suggested by $V$. hemipterus, the larvae of which develop in deciduous trees. The decaying dung of large mammals is suggested by the dung beetle Onthophagus sp. and mould beetle Corticarina sp.

This assemblage may represent a low-energy fluvial environment. There is some evidence for relatively shallow water with aquatic vegetation and reedbeds fringed by wet woodland containing willow, and expanses of open meadow. There are also some indicators of dry chalk grassland, for example, the ground beetle Bembidion quadrimaculatum.

\subsubsection{Dating}

Optically stimulated luminescence (OSL) dating of quartz gave an age of $137.74 \pm 41.65$ years BP for the base of the silty clay unit (analyzed by B. Briant). This appears to indicate a correlation with the Eemian (MIS 5e). Amino acid racemization analyses for Valvata shells from the basal silty clay gave D/L ratios of 0.117 and 0.133 (analyzed by C.P. Hart). These ratios also equate to an Eemian (MIS 5e) age. 


\subsubsection{Interpretation}

The gravels at Abington Hall were most likely deposited by a braided stream within a confined valley system. The sequence of silty clay was clearly truncated by the overlying gravel. It appears that these sediments represent the silting up of a slow-moving river channel with emergent vegetation, and nearby dry grassland and deciduous woodland during a phase of climatic warming. It appears that these sediments record the beginning of the Eemian (MIS 5e) based on optically stimulated luminescence (OSL) and amino acid racemization dating.

\subsection{Geological Section 5-Barrington Works Chalk Quarry (Chapel Hill)}

This ca. 750-m long section (Figure 6) is aligned roughly northwest-southeast across the edge of the Elsterian till plateau (Chapel Hill) at ca. 50 m O.D. north of Barrington. The deposits described here no longer exist, having been quarried away by the Barrington Works. In the section, to the northwest, ca. $4.5 \mathrm{~m}$ of chalky diamicton once overlaid West Melbury Formation Chalk Formation bedrock, but rapidly thinned down slope towards the southeast. An exposure in this diamicton (glacial till) has been proposed as the type section of the Barrington Works Member of the Lowestoft Formation of Elsterian (MIS 12) age [9]. Further downslope, the section runs across in-filled dry valleys. The deposits here are characterised by ca. $3 \mathrm{~m}$ of pellet chalk with a chalk putty matrix overlain by ca. $3 \mathrm{~m}$ clay with gravel.

\section{Barrington Works - Geological Section}

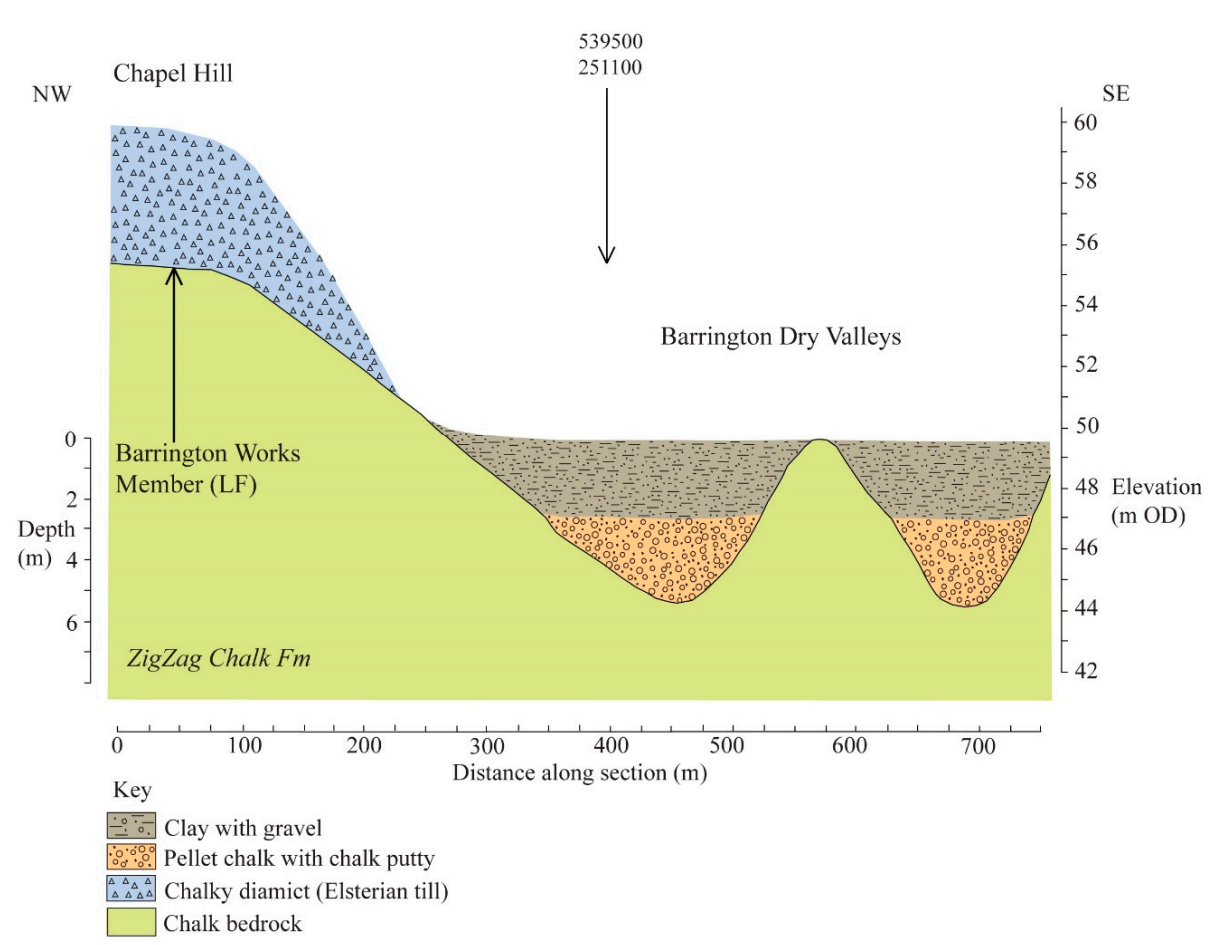

Figure 6. Geological Section 5 at Barrington Works across the till plateau of Chapel Hill and the Barrington Dry Valleys.

\subsection{Barrington Dry Valley Deposits}

The dry valley deposits from Barrington Works are known to contain molluscs [31]. The clay with gravel unit and underlying pellet chalk were thought to have entirely different origins. In the past, exposures of dry valley in-fillings and the chalky diamicton were more extensive [39]. Newer exposures of chalky diamicton were attributed the Elsterian glaciation, and demonstrated that the dry valley deposits clearly post-dated the chalky diamicton, with reworked material giving the impression of stratigraphic complexity in the dry valley systems [42]. 


\subsubsection{Molluscs}

Analysis of molluscs from the dry valley deposits showed that the fauna of the pellet chalk indicated climatic conditions similar to those in northern Scandinavia or perhaps central Europe today [30]. In contrast, the clay with gravel unit, which was thought partly to be a palaeosol, contained an early Holocene mollusc fauna, based on the absence of Helix aspersa, with elements indicating both open ground and woodland, and with a climate at least as warm as the present day [31].

\subsubsection{Interpretation}

The chalky till (Barrington Works Member LF) is thought to have been deposited beneath Elsterian ice advancing towards the south [42]. It appears likely that there was a considerable interval of time between the deposition of the chalky diamicton and the formation of the dry valleys and their contained deposits. The chalk pellet unit suggests the widespread destruction of chalk bedrock by periglacial processes. Solifluction processes within the active layer of permafrost are known to transport the regolith downslope. Cold conditions are also indicated by the contained mollusc fauna. Although there is little direct evidence, it appears that this deposit is probably Late Weichselian (Late Glacial) in age. The overlying clay with gravel unit seems to represent an early Holocene soil and subsequent colluvial slopewash (Atlantic-late Mesolithic/early Neolithic ca. 5700-7800 Cal years BP). Both units are principally terrestrial deposits with little evidence of stream action, and as such, do not easily fit into the lithostratigraphic scheme used elsewhere in this paper, although the nearest equivalent would be the Jesus Green Member (CVF).

\subsection{Geological Section 6-Clarke's Hill}

This ca. 600-m long section (Figure 7) is aligned roughly southwest-northeast across a low ridge leading northwest from Wandlebury and the Gog Magog Hills. The summit of Clarke's Hill reaches ca. $46.5 \mathrm{~m}$ O.D. In the section, to the southwest, ca. $3.5 \mathrm{~m}$ of cobbles and fine gravel can be seen overlying chalk bedrock, but this rapidly thins towards the northeast, and is replaced by a thin mantle of sandy silt.

Clarke's Hill - Geological Section

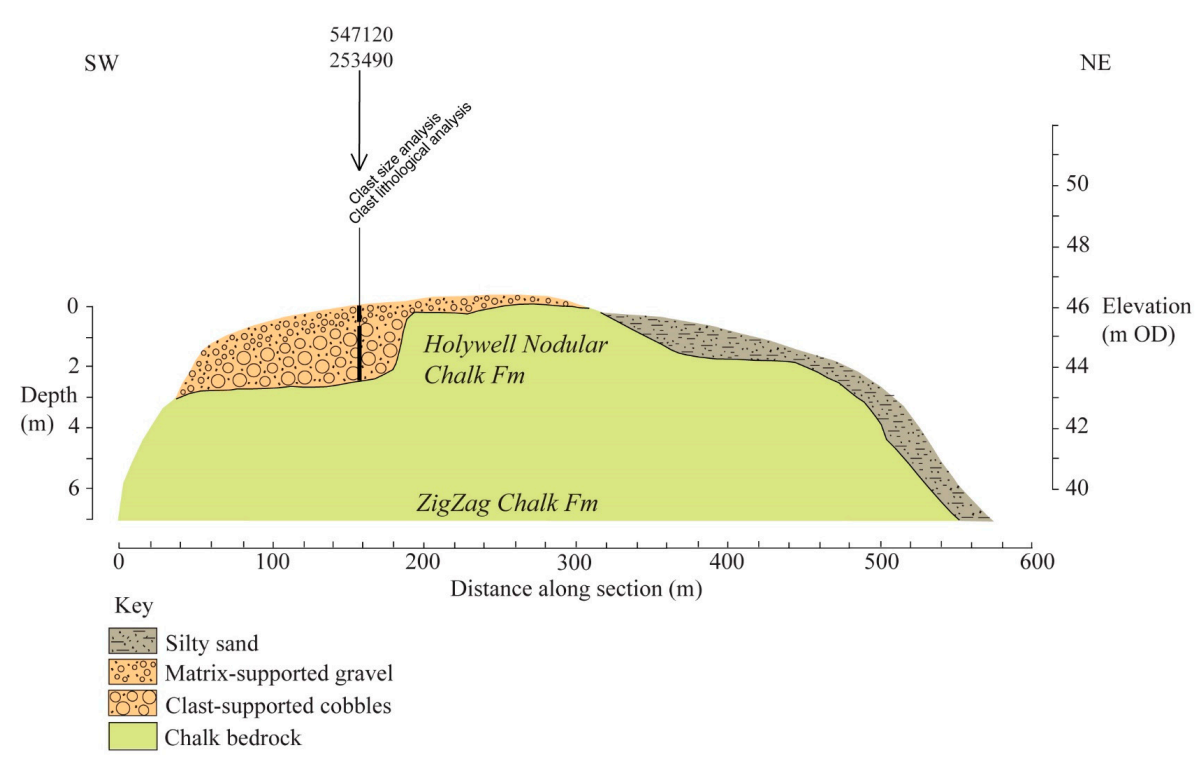

Figure 7. Geological Section 6 at Clarke's Hill across cobble gravel and bedrock chalk, showing the position of samples for clast lithological analysis. 


\subsection{Clarke's Hill Gravels}

A trench cut for an archaeological investigation near the crest of Clarke's Hill, Great Shelford, exposed a unit of chaotically-bedded clast-supported cobbles ca. 2-m thick, overlain by a matrixsupported medium to fine grade gravel with indistinct inclined bedding ca. 1.5-m thick.

\subsubsection{Clast Size and Clast Lithology}

SB analysed the gravels from Clarke's Hill. A large bulk sample taken from the cobble unit contained 57 clasts between $50-280 \mathrm{~mm}$ in length, with the majority $(66.7 \%)$ in the $64-128 \mathrm{~mm}$ size class. The largest clast, a boulder of Jurassic fossiliferous limestone $280-\mathrm{mm}$ long, weighed $12.5 \mathrm{~kg}$. In contrast, the overlying matrix-supported gravel unit contained very few large clasts $(1.9 \%)$ in the $16-32 \mathrm{~mm}$ size range, with the majority $(98.5 \%)$ in the $8-11.2 \mathrm{~mm}$ size class.

The significance of the coarse grade of these cobbles is highlighted by the lack of pebbles $>64 \mathrm{~mm}$ in any other Cam valley samples analysed by the author. It is clear that the clast size distributions represent two very different depositional regimes. The cobble unit must represent a high-energy environment, whilst the overlying matrix-supported gravel is typical of deposition by a small stream.

Many of the limestone cobbles were clearly derived from the Carboniferous Limestone, rather than local Jurassic sources. In addition, other far-travelled cobbles were composed of granite, schist, Millstone Grit, and Whin Sill dolerite. This resulted in a large (ca. 50\%) exotic component, with ca. $40 \%$ local lithologies and ca. 10\% chalk and flint. Conversely, the overlying matrix-supported gravel contained $1.9 \%$ exotics, $18 \%$ local lithologies, $21.4 \%$ flint, and $58.7 \%$ chalk. The two samples clearly have thoroughly different clast lithologies and provenance.

\subsubsection{Interpretation}

The coarse grade of the cobbles and the large exotic component of the clasts suggest a high-energy sub-glacial or pro-glacial environment of deposition. In contrast, the overlying predominantly medium-grade flint and chalk gravel unit appears to have been laid down by a relatively small stream draining a catchment dominated by chalk bedrock. The elevated position of the cobble deposits and the obvious glacial derivation strongly suggest an association with the Elsterian (MIS 12) ice sheet and probably represent the Observatory Member of the Lowestoft Formation.

\subsection{Geological Section 7-Cantelupe Farm, Trumpington \& Babraham Road}

This 6-km long section (Figure 8) is aligned roughly west-east from Cantelupe Farm, across the River Cam floodplain at Byron's Pool, Trumpington, and the valley of Hobson's Brook towards Babraham Road. The dip of the bedrock towards the east can be seen in this section, with the West Melbury Chalk Formation overlying the Gault Formation. At Cantelupe Farm, ca. $2 \mathrm{~m}$ of sand and gravel (second terrace deposits-Sidgwick Avenue Member CVF) represent the mid-Weichselian course of the Bourn Brook.

At Byron's Pool, the River Cam floodplain is relatively wide near the confluence of the Bourn Brook, and characterised by alluvial silty clay directly overlying both peat and gravel. The floodplain is underlain by a channel form ca. $6 \mathrm{~m}$ deep that is incised into the Gault Clay Formation. It is filled by ca. $1 \mathrm{~m}$ of late-Weichselian upper sand and gravel (first terrace deposits Barnwell Station Member CVF) contiguous with ca. $2 \mathrm{~m}$ of late-Weichselian basal sand and gravel (Midsummer Common Member CVF). This is overlain by ca. $2.5 \mathrm{~m}$ of peat and ca. $2 \mathrm{~m}$ of alluvial silty clay (Jesus Green Member CVF). 


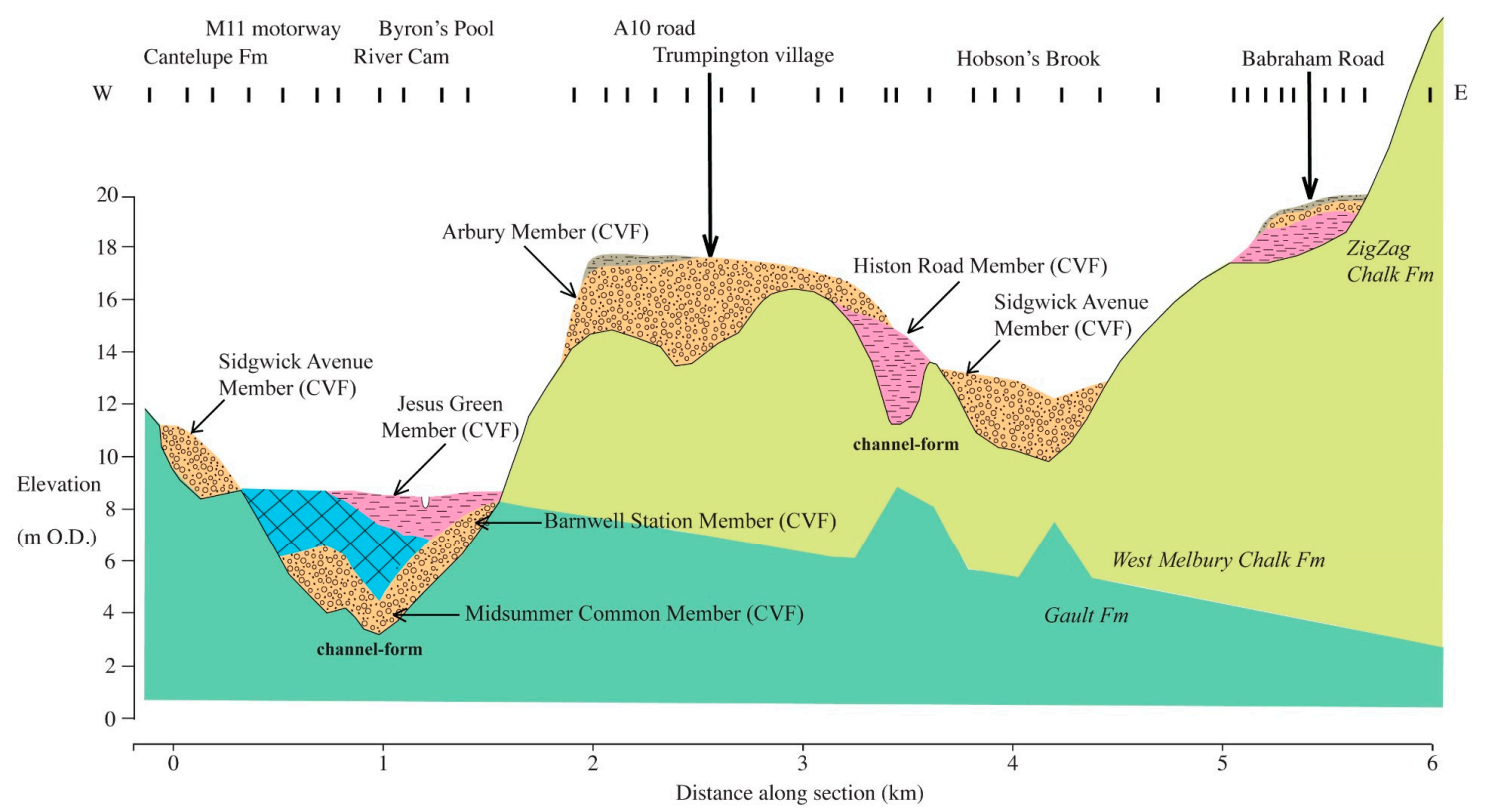

Figure 8. Geological Section 7 through the Cam valley at Byron's Pool, Trumpington village and the Hobson's Brook valley to Babraham Road constructed from borehole records.

At Trumpington village, a small channel form ca. $5 \mathrm{~m}$ deep incised into the West Melbury Chalk Formation is filled by ca. $4 \mathrm{~m}$ of silty clay (Histon Road Member CVF) and overlain sand and gravel (third terrace deposits Arbury Member CVF) that to the west reaches ca. 4-m thick. The Trumpington village deposits, which appear to be the early-Weichselian course of the River Cam, are described in Section 5.13. below. To the east, the valley of Hobson's Brook is underlain by ca. $3 \mathrm{~m}$ of sand and gravel (second terrace deposits: Sidgwick Avenue Member CVF) that represent the mid-Weichselian course of the River Cam incised into the older third terrace deposits. Further east at Babraham Road, ca. $1 \mathrm{~m}$ of silty clay is overlain by pellet chalk and gravel at the foot of a rising chalk slope. This area is within an 'embayment' formed by the 20-m contour (see Figure 1). The Babraham Road deposits, which appear to represent a late-Weichselian lake bed, are described in Section 5.14 below.

\subsection{Trumpington Village Deposits}

A 3.5-m high section in gravel and sand with silt lenses in a railway cutting at Trumpington village was mapped by the BGS as the third terrace (Arbury Member CVF) $[30,43]$ and known to contain molluscs [40].

\subsubsection{Molluscs}

Molluscs were recovered from two distinct silty lenses $2.4 \mathrm{~m}$ and $3.4 \mathrm{~m}$ below the surface [20]. The combined assemblage comprised a mixture of dry grassland species such as Pupilla muscorum, the taxa of marshlands, floodplains, and stagnant pools, aquatic types indicating slow flowing well-oxygenated conditions, and snails of temperate woodland habitats (Ena montana, and Clausilia sp.). The thermophilous elements in this assemblage invited the correlation of this site with Grantchester Church (see Section 5.16 below), although the temperate part of this assemblage is rather small, and several other important thermophilous taxa are absent, including Azeca. menkeana [44]. It is difficult to give an unequivocal interpretation of the molluscan data, but there is evidence for a slow-flowing river with a marshy floodplain and pools in a grassland environment. Assuming that the thermophilous elements are not reworked, there is also evidence for some temperate woodland within the catchment. 


\subsubsection{Interpretation}

The 'fine to medium, sandy, and chalky gravel' exposed in the railway cutting were presumably deposited by a braided river system under generally cool or cold conditions. The presence of marshland and pools on the surface of the braidplain is clearly shown by the molluscan fauna. There is some evidence of more temperate conditions, which were presumably accompanied by a less energetic flow regime. It appears that either such conditions did not persist for long, or the evidence for them has been largely removed. The stratigraphic position of these gravels within the third terrace and above silty clay of the Histon Road Member suggests that they probably date from the early-Weichselian period (MIS 4).

\subsection{Babraham Road Deposits}

In 1998, archaeological trenches at the Babraham Road Park and Ride site revealed a unit of carbonate-rich silty clay ca. 1-m thick containing tubules and oospores of the alga Chara overlain by a unit of chalk putty ca. 1-m thick composed of chalk pellets in a carbonate matrix, and a thin upper sand and gravel unit with occasional deeper scours. The BGS map does not show superficial deposits in this area [45].

\subsubsection{Pollen and Plant Macrofossils}

Pollen and plant macrofossil analysis by SB of the basal silty clay produced pollen assemblages dominated by Poaceae (grass) and herbs. The only arboreal pollen was Betula (birch), and the aquatic habitat suggested by the occurrence of plant macrofossils of Chara oospores and tubules was confirmed by the presence of Nuphar (yellow water-lily) pollen. This limited pollen assemblage is interpreted as representing open grassland, perhaps with birch scrub, surrounding a pool or lake. However, the Betula pollen might originate from dwarf birch rather than from trees.

\subsubsection{Dating}

An optically stimulated luminescence (OSL) date (analysed by M. Bateman) from sand within the silty clay gave an age of 14,200 \pm 2300 years BP, indicating a Late Glacial, and possibly Allerød (Windermere Interstadial) age for these sediments [3].

\subsubsection{Interpretation}

The plant macrofossil and pollen evidence suggests that the basal silt unit represents a late-Weichselian (MIS 2) lake bed formed during a relatively temperate interval. Therefore, the overlying chalk putty might originate from intense periglacial activity during the Loch Lomond Stadial (Younger Dryas) ca. 11,000 to 10,000 years BP, with the overlying gravel representing deposition by small streams emanating from nearby chalk springs. These terrestrial and lake deposits do not fit easily into the lithostratigraphic scheme used elsewhere in this paper, although the nearest equivalent would be the Midsummer Common Member (CVF).

\subsection{Geological Section 8-Grantchester to Cherry Hinton Road}

This 5.5-km long section (Figure 9) is aligned roughly southwest-northeast from Grantchester Church, across the River Cam floodplain and the valley of Hobson's Brook towards Cherry Hinton Road in southern Cambridge. The dip of the bedrock towards the east can be clearly seen, with the West Melbury Chalk Formation overlying the Gault Formation. 


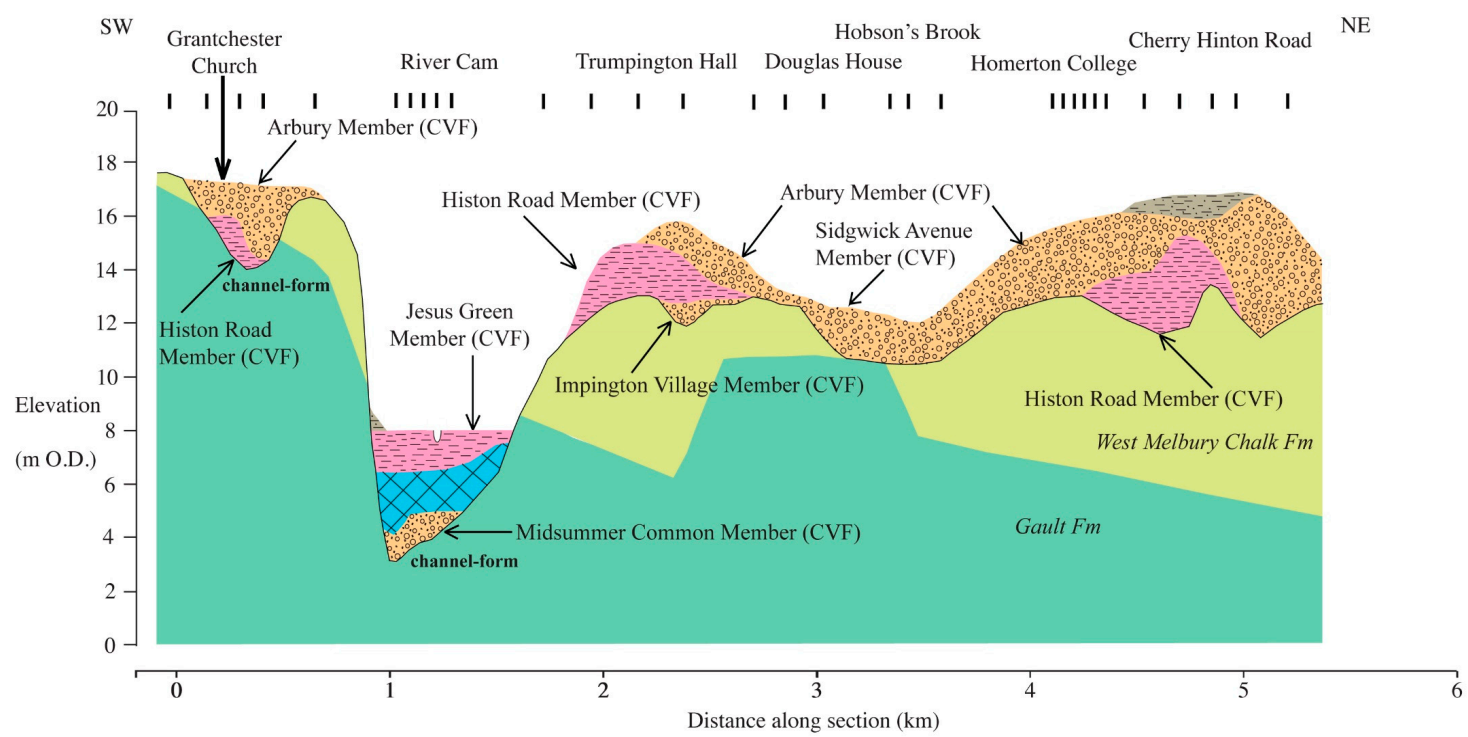

Figure 9. Geological Section 8 from Grantchester Church across the Cam valley and the Hobson's Brook valley to Cherry Hinton Road constructed from borehole records.

At Grantchester Church, the West Melbury Chalk Formation mantles the valley side reaching ca. $17.5 \mathrm{~m}$ O.D. and is incised by a channel form ca. $3.5 \mathrm{~m}$ deep and filled by ca. $2 \mathrm{~m}$ of silt (Histon Road Member CVF) and ca. $3 \mathrm{~m}$ of sand and gravel (third terrace deposits Arbury Member (CVF)). The Grantchester Church deposits, which appear to be a course of the Bourn Brook dating from the Saalian, are described in Section 5.16 below.

At Grantchester village, the River Cam floodplain is quite narrow and characterised by alluvial silty clay overlying peat (Jesus Green Member CVF) and gravel. The floodplain is underlain by a channel form ca. $5 \mathrm{~m}$ deep incised into the Gault Clay Formation, filled by ca. $2 \mathrm{~m}$ of late-Weichselian basal sand and gravel (Midsummer Common Member CVF) and ca. $3 \mathrm{~m}$ of peat (Jesus Green Member CVF). At Trumpington Hall, the basal gravel of the Impington Village Member is overlain by ca. $2.2 \mathrm{~m}$ of silty clay (Histon Road Member CVF); in turn, these are overlain by ca. $2 \mathrm{~m}$ of sand and gravel (third terrace deposits Arbury Member CVF), which represent the early-Weichselian course of the River Cam.

To the northeast, the valley of Hobson's Brook is underlain by ca. $2 \mathrm{~m}$ of sand and gravel (second terrace deposits-Sidgwick Avenue Member CVF) that represent the mid-Weichselian course of the River Cam incised into the older third terrace deposits. Further northeast at Cherry Hinton Road, ca. $3 \mathrm{~m}$ of silty clay (Histon Road Member CVF) is overlain by ca. $3 \mathrm{~m}$ of sand and gravel (third terrace deposits Arbury Member CVF) that forms a ridge reaching ca. $17 \mathrm{~m} \mathrm{O.D.} \mathrm{and} \mathrm{represents} \mathrm{the}$ early-Weichselian course of the River Cam.

\subsection{Grantchester Church Deposits}

A 3-m high section in gravel, sand, and silt was once exposed by coprolite mining at Grantchester Church, mapped by the BGS as the third terrace (Arbury Member/Histon Road Member (CVF) [26]. It comprised $2 \mathrm{~m}$ of chalky gravel overlying marl and peaty silt containing bands full of land and freshwater shells. The site is now obscured by backfill.

\subsubsection{Pollen}

SB attempted pollen analyses from two blocks of sediment from the site preserved in the Sedgwick Museum, Cambridge. One sample proved to be barren, whilst the other yielded a low concentration of palynomorphs dominated by Poaceae (grass) and herbs. 


\subsubsection{Molluscs}

Molluscs have been collected from the Grantchester Church site for many years, although the exposure is now obscured $[26,30,44,46]$. Collections of these shells are now held in the Sedgwick Museum. The interglacial nature of the assemblage is clear, with Azeca. menkeana, Ena montana, and Clausilia pumilla all indicating warm, and perhaps continental conditions. Woodland habitats are indicated by these taxa, and by Clausilia sp. and Carychium tridentatum. Marshland and dry grassland taxa (for example Pupilla muscorum) dominated the land molluscs. The freshwater molluscs were characteristic of moving water environments, marshland, and pools. The absence of Belgrandia marginata and Corbicula fluminalis from these deposits is a notable feature of this assemblage. Considerable stratigraphic significance has been attached to the relative presence or absence of these two species, although they are not universally present in the deposits of British temperate stages $[32,33]$. In the past, this assemblage has been attributed to the last interglacial (Eemian MIS 5e) [44].

\subsubsection{Vertebrates}

Vertebrate remains were also recovered from the deposits at Grantchester Church [26,40], and there is a collection in the Sedgwick Museum. The mammals represented include many that were believed to favour grassland habitats such as Crocuta crocuta (spotted hyena), Equus ferus (horse), Panthera leo (lion), Bos primigenius (aurochs), Bison priscus (bison), and Megaloceros giganteus (giant deer). In addition, SB found teeth of Mammuthus primigenius (mammoth) from the site to be relatively abundant in the Sedgwick Museum collection. This assemblage appears to resemble the Mammuthus trogontherii-primigenius/Equus ferus fauna correlated with MIS 7. Remains of Cervus elaphus (red deer), Canis lupus (wolf), and Ursus arctos (brown bear), which are elements of the 'hippopotamus fauna' associated with the Eemian Stage (MIS 5e), are also present [34,35], although Hippopotamus amphibius (hippopotamus), Palaeoloxodon antiquus (straight-tusked elephant), and Dama dama (fallow deer) are plainly absent. This confuses the potentially invaluable biostratigraphic information to a degree, although the authors consider it likely that bones from a variety of strata in the Grantchester pit may have been collected and combined to give this chimeric signal.

\subsubsection{Dating}

Amino acid racemization analyses for Valvata piscinalis shells from the peaty silt held by the Sedgwick Musem gave D/L ratios of 0.147, 0.160, 0.191, and 0.202 [3] (analysed by C.P. Hart). The lowest pair of these ratios equate to an age in the later part of the Saalian complex (MIS 6/7) age, whilst the other two indicate dates within the middle part of the Saalian complex (MIS 7/8). This mixed amino acid signal means that a minimum age estimate for the last phase of deposition based on the lowest $\mathrm{D} / \mathrm{L}$ ratios is within the later part of the Saalian complex (MIS 6/7). Given the nature of the molluscan and vertebrate fauna, the authors conclude that this deposit correlates with a temperate part of MIS 7 . The apparent age distribution of these well-preserved shells suggests a reworking of older deposits from locally exposed sources dating from the middle of the Saalian complex.

\subsubsection{Interpretation}

The gravel and sand containing beds of organic silty clay at Grantchester Church were evidently deposited in a fluvial environment. The original 19th century hand-drawn geological section clearly shows the sediment filling minor channels, and she comments that the deposits seem 'to indicate the shifting channels of a river wandering over a tolerably wide area' [26]. Previous assessments concluded that 'the Grantchester deposit was laid down by the Cam itself, and not in any minor tributaries or marshes on its floodplain' [44]. However, the position of this site on a distal fragment of the third terrace does not easily lend itself to this conclusion. The relative abundance of gravel and sand in the deposit indicates episodes of higher energy, and the apparently shifting channels are not what one might expect from a stable single-thread low-energy temperate stream in a well-vegetated 
catchment. The authors suggests that these apparent contradictions might in part be explained if the deposits represent those close to the confluence of an earlier course of the Bourn Brook with the River Cam. The mollusc fauna indicates a temperate climate, with at least some woodland in the catchment. Despite this, pollen, mollusc, and vertebrate evidence show that open grassland environments were an important part of the landscape. There is relatively strong biostratigraphic evidence that this deposit was laid down during a temperate part of MIS 7. This interpretation is supported by the amino acid racemization analyses for Valvata shells, which suggest an age at the end of the Saalian complex (MIS 6/7). However, there is some evidence for the reworking of material from older deposits.

\subsection{Geological Section 9-Grantchester to Hauxton}

This 6-km long section (Figure 10) is aligned roughly northwest-southeast from the M11 motorway at Grantchester, across the River Cam floodplain near Byron's Pool and the A10 road south of Trumpington, to the valley of the River Cam at Hauxton. The dip of the bedrock towards the southeast can be seen in this section, with the West Melbury Chalk Formation overlying the Gault Formation.

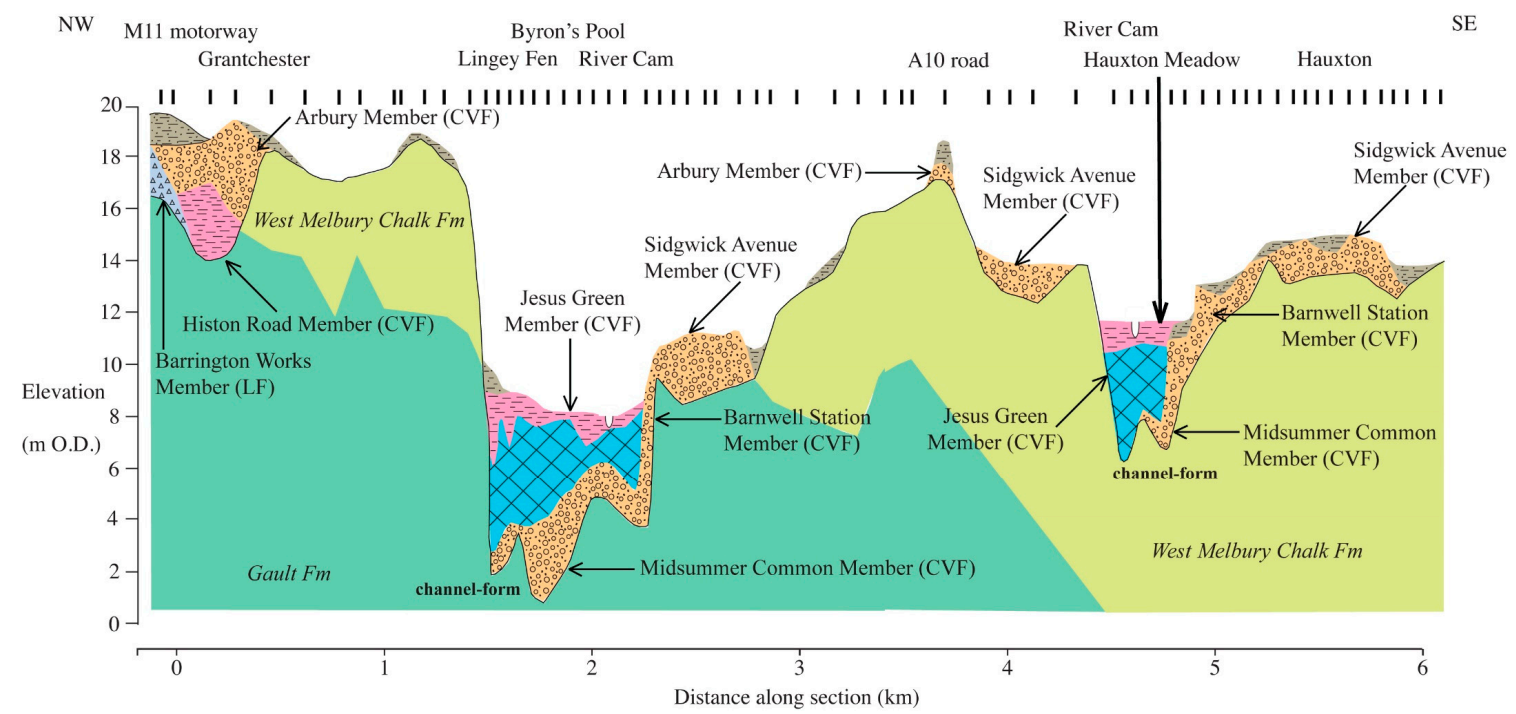

Figure 10. Geological Section 9 from Grantchester across the Cam valley at Byron's Pool, and across the Cam valley at Hauxton Meadow constructed from borehole records.

Close to the M11 motorway at Grantchester, a channel-form ca. $4 \mathrm{~m}$ deep incised into both the bedrock and a diamicton (till) of the Barrington Works Member (LF) is filled by ca. $2.5 \mathrm{~m}$ of silt (Histon Road Member CVF) and ca. $3 \mathrm{~m}$ of sand and gravel (third terrace deposits Arbury Member (CVF)). The deposits here are equivalent to those at Grantchester Church (see Section 5.16 above), which appear to represent the course of the Bourn Brook dating from the early-Weichselian and older.

Upstream of Byron's Pool, the River Cam floodplain is relatively wide near the confluence of the Bourn Brook, and characterised by alluvial silty clay overlying peat and gravel. The floodplain is underlain by a channel-form ca. $7 \mathrm{~m}$ deep incised into the Gault Clay Formation. It is filled by ca. $1 \mathrm{~m}$ of late-Weichselian upper sand and gravel (first terrace deposits Barnwell Station Member CVF) and ca. $2.5 \mathrm{~m}$ of late-Weichselian basal sand and gravel (Midsummer Common Member (CVF)). This is overlain by ca. $3.5 \mathrm{~m}$ of peat and ca. $1.5 \mathrm{~m}$ of alluvial silty clay (Jesus Green Member (CVF)). Adjacent to the floodplain, ca. $2 \mathrm{~m}$ of sand and gravel (second terrace deposits-Sidgwick Avenue Member CVF) represent a mid-Weichselian course of the Bourn Brook. To the south, a small patch of gravel and sand at $17.5 \mathrm{~m}$ O.D. on the interfluve is present beneath the A10 road at Trumpington. It belongs to the third terrace (Arbury Member CVF) and represents the now much denuded early-Weichselian course of the River Cam. 
The River Cam valley at Hauxton Meadow is flanked on either side by ca. $1.5 \mathrm{~m}$ of sand and gravel (second terrace deposits-Sidgwick Avenue Member CVF) that represent the dissected mid-Weichselian braidplain of the River Cam. In a microcosm of the stratigraphy at Byron's Pool, sand and gravel belonging to the late-Weichselian first terrace deposits Barnwell Station Member (CVF) and (Midsummer Common Member CVF) occupy a ca. 6-m deep channel form incised into the chalk bedrock, and are overlain by peat and alluvial silty clay (Jesus Green Member CVF). The Holocene deposits have been investigated in detail at Hauxton Meadow and are described in Section 5.18 below.

\subsection{Hauxton Meadow Deposits}

The ca. 50-m long section shown in Figure 11 is aligned south-north across the floodplain of the River Cam, and provides detail of the Middle Cam Holocene sediments. The sequence includes Late Glacial basal gravel and sand (Midsummer Common Member CVF) and four units (A-D) of Holocene deposits. The Holocene deposits (Jesus Green Member CVF) comprised sandy and silty sediments (unit A), allochthonous water-lain detrital peat, and autochthonous peat (unit B-Peat (FF)) overlain by alluvial silty clay (unit $\mathrm{C}$ ). In one location, a palaeochannel (BH3) was occupied by alluvium (unit C) and silty sand (unit D).

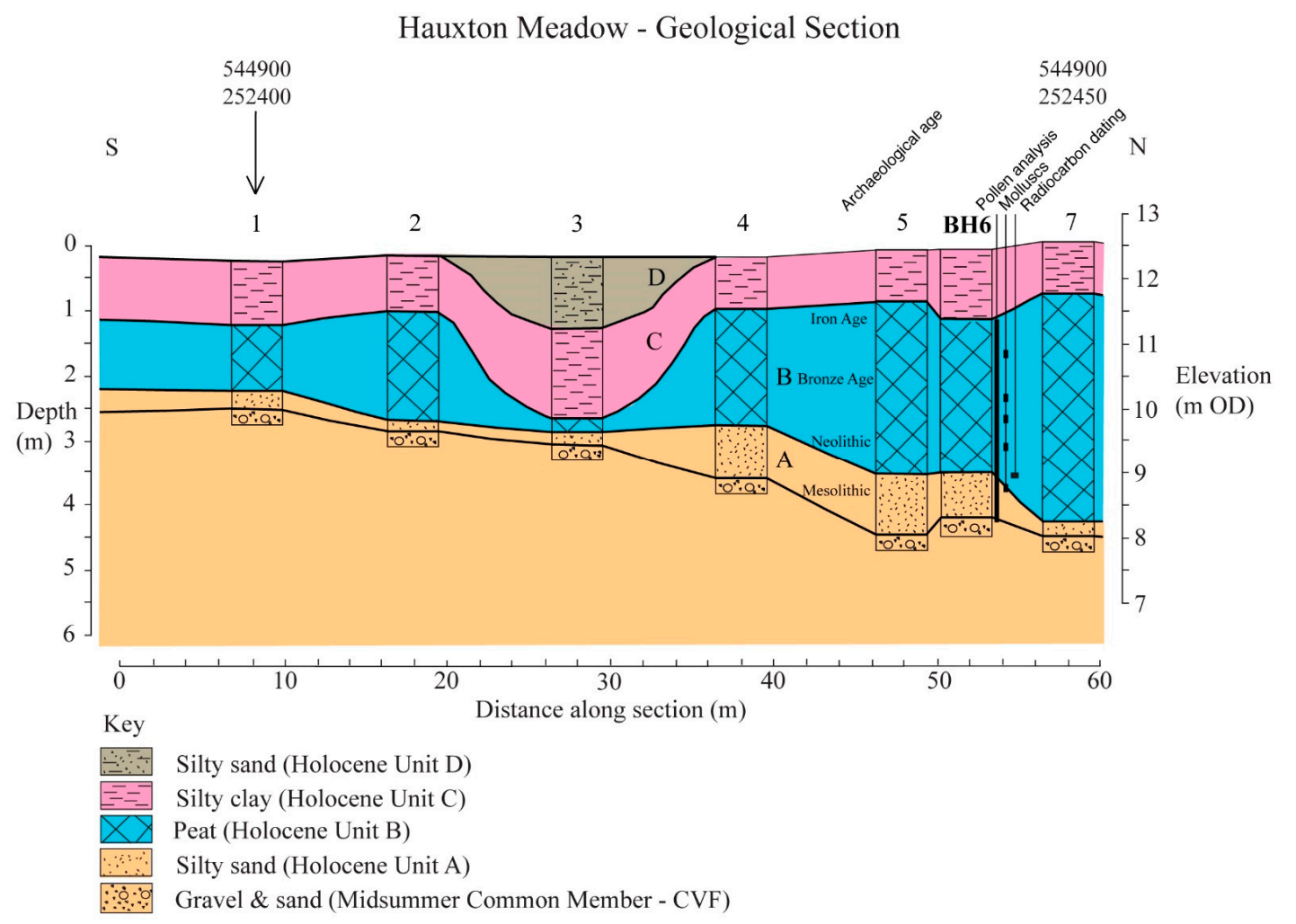

Figure 11. Geological section across the floodplain at Hauxton Meadow constructed from borehole records, showing the position of samples for pollen analysis, mollusc analysis, and radiocarbon dating in BH6.

\subsubsection{Pollen}

KL undertook pollen analysis from the sediments at BH6 (see Figure 11). This sequence (Figure 12) has many features of a typical Holocene pollen diagram. Although a dry-land signal from the catchment is present, much of the pollen is derived from the local in-channel vegetation of the river. To facilitate the description of vegetational changes, the pollen diagram has been divided into four main pollen assemblage biozones (PABs). 


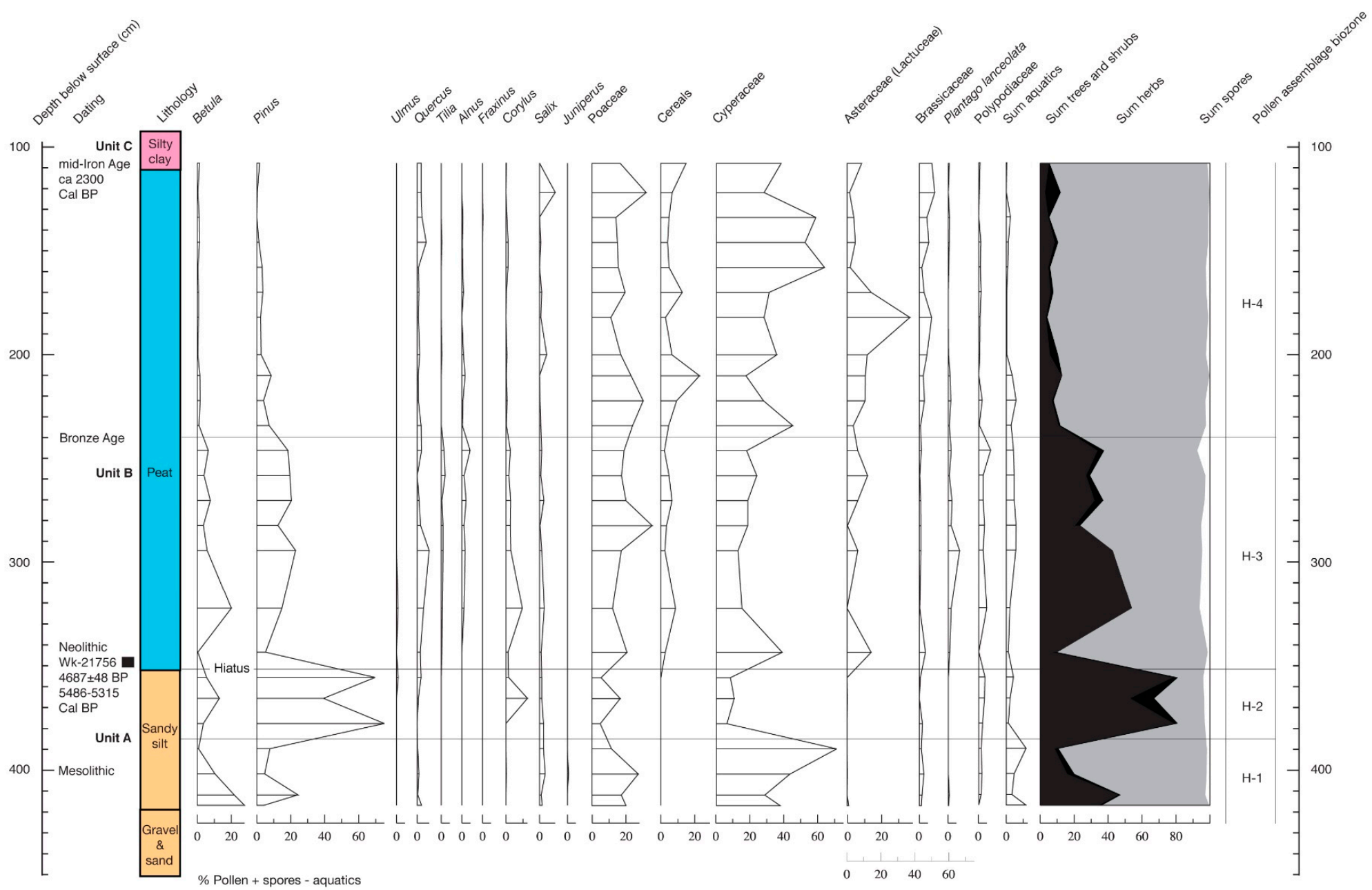

Figure 12. Summary percentage pollen diagram of selected taxa from Hauxton Meadow BH6. 
The basal PAB H-1 (416 cm, $385 \mathrm{~cm}$ Unit A) is characterized by the dominance of non-arboreal pollen (NAP), including sedges (Cyperaceae), grasses (Poaceae), and fern spores (Polypodiaceae). Aquatics including broad-leaved pond weed (Potamogeton), bur-reed (Sparganium), and reedmace (Typha latifolia) together exceed 5\%. Trees and shrubs were dominated by pine (Pinus) and birch (Betula) with low proportions of hazel (Corylus), willow (Salix), and juniper (Juniperus).

PAB H-2 (385 cm, $352 \mathrm{~cm}$ Unit A) is characterized by a substantial increase in trees and shrubs, with pine (Pinus) proportions exceeding 40\%, and the presence of birch (Betula), hazel (Corylus), and willow (Salix) pollen throughout. Oak (Quercus) and elm (Ulmus) are also present at to top of this zone. Non-arboreal pollen (NAP) is mainly represented by sedges (Cyperaceae), grasses (Poaceae), and fern spores (Polypodiaceae).

PAB H-3 (352-240 cm Unit B) is characterised by NAP, including sedges (Cyperaceae), grasses (Poaceae), fern spores (Polypodiaceae), and members of the lettuce family (Asteraceae (Lactuceae)), with cereal pollen exceeding $5 \%$. The disturbance indicator ribwort plantain (Plantago lanceolata) was also present throughout. Tree and shrub pollen were represented by pine (Pinus), birch (Betula), oak (Quercus), elm (Ulmus), lime (Tilia), alder (Alnus), hazel (Corylus), and willow (Salix). Obligate aquatics such as bur reed (Sparganium), reedmace (Typha latifolia), and broad-leaved pond weed (Potamogeton) were continuously present.

The upper PAB H-4 $(240 \mathrm{~cm}, 108 \mathrm{~cm}$ Unit B) is characterised by the dominance of NAP, including sedges (Cyperaceae), grasses (Poaceae), members of the lettuce family (Asteraceae (Lactuceae)), members of the cabbage family (Brassicaceae), and abundant cereal pollen. Tree and shrub pollen was represented by the low and discontinuous presence of pine (Pinus), birch (Betula), oak (Quercus), ash (Fraxinus), lime (Tilia), alder (Alnus), hazel (Corylus), and willow (Salix). Aquatic pollen declined towards the top of the zone, suggesting the onset of more terrestrial conditions.

\subsubsection{Molluscs}

Five samples from the sequence analysed by KL produced mollusc data. Aquatic taxa associated with abundant vegetation and slow-moving water such as Pisidium nitidum, Valvata cristata, Valvata piscinalis, Bithynia tentaculata, Lymnea truncatula, and Lymnaea peregra dominated the assemblages in the basal three samples $(373 \mathrm{~cm}, 310 \mathrm{~cm}$, and $265 \mathrm{~cm})$. However, the upper two samples $(235 \mathrm{~cm}$ and $165 \mathrm{~cm}$ ) contained large proportions of land snails, including Carychium minimum, Succinea sp., and Vallonia pulchella, indicating meadows and marshland nearby.

\subsubsection{Dating}

The bulk radiocarbon date from 345-350 cm was $4687 \pm 48 \mathrm{BP}(\mathrm{Wk}-21756)$, which calibrates at $78.1 \%$ probability to $5486-5315$ Cal BP and places the basal part of the sandy detrital peat unit (unit B) in the mid-Neolithic (mid Holocene).

\subsubsection{Interpretation}

The pollen evidence indicates that the basal sediments (unit A) formed in a pool or pond. This is interpreted as an abandoned channel in the surface of the underlying Late Weichselian gravel and sand, and dates from the early Holocene (early Mesolithic). In particular, the basal deposits (unit A) with birch and herb pollen of PAB H-1 may date from the Pre-Boreal (Mesolithic) period (11,500-10,500 Cal $\mathrm{BP})$, and the pine peak of PAB H-2 probably represents the first part of the Boreal period $(10,500-9500$ $\mathrm{Cal} \mathrm{BP}$ ) before the rise of hazel (Corylus). However, the characteristic early Holocene pollen succession seen elsewhere in the Cam floodplain is absent [1,2]. This suggests a significant hiatus in deposition between unit A and unit B (dated to the mid-Neolithic (5486-5315 Cal BP)). The main river channel was clearly located elsewhere during the Atlantic period (7800-5700 Cal BP), and it was only during the mid-Neolithic that fluvial conditions returned to the vicinity of BH6.

The detrital peat of unit $B$ represents deposition in a well-vegetated, slow-moving river channel (PAB H-3), which subsequently became a marshy floodplain meadow (PAB H-4) until the onset of 
alluvial silty clay deposition (unit C). There is strong evidence for arable farming, soil disturbance, and progressive tree clearance from the late Neolithic onwards. By the mid-Iron Age, in response to continued woodland clearance in the catchment causing increased sediment load from soil erosion, the River Cam - similar to many other rivers in southern England-had begun to flood each winter, leading to the deposition of over-bank fines (alluvium). The palaeochannel seen at BH3 (Figure 5) appears to date from this period. In southern England, the 'Romano-British silt' is usually thought to have commenced deposition in the mid-Iron Age (ca. $2300 \mathrm{Cal} \mathrm{BP).} \mathrm{Thus,} \mathrm{unit} \mathrm{B} \mathrm{is} \mathrm{interpreted} \mathrm{to} \mathrm{span}$ some 3000 years of the sub-Boreal period, including the late Neolithic, Bronze Age, and early Iron Age.

\section{Discussion and Conclusions}

The geology map (Figure 1) and geological cross-sections (Figures 2-11) provide a valuable insight into the bedrock geology, and the Holocene and Pleistocene stratigraphy beneath different parts of the Middle Cam valley. Table 1 lists the sites and deposits described in detail within the text in chronostratigraphic order.

The Elsterian (MIS 12) glaciogenic (Lowestoft Formation) deposits in the Middle Cam valley occupy a variety of settings ranging from the till plateau at Barrington Works (Chapel Hill) and the 'tunnel valley' deposits of Whittlesford Station to isolated patches of exotic-rich gravels at Clarke's Hill. There are a number of gravel deposits in the area capping hills and interfluves, which were also interpreted to be of Elsterian age. There is a notable absence of deposits in the Middle Cam valley attributable to the Holsteinian (MIS 11) and the early Saalian complex (MIS 10-8). Whilst the Middle Cam is located south of the putative limit of the Saalian (MIS 8) glaciation, which is known from the Trent valley [4], the erosion of earlier sediments may have been driven by intense periglacial activity at this time. It seems likely that fluvial deposits of early Saalian age were once present, but have either been removed by later incision or severely degraded by polycyclic (Saalian and Weichselian) periglacial activity. It is also possible that they remain hidden within the tunnel valley deposits of the Cam valley.

The fluvial (Cam Valley Formation) deposits of the late Saalian complex (MIS 7) are represented by silts (Histon Road Member) beneath tributary gravels at Grantchester Church, and by silts within the very basal gravel (Impington Village Member) at Cardo's Pit, Barrington village. The paucity of deposits of this age in the Middle Cam valley hints at their relatively low preservation potential, suggesting that they have often been removed by later incision. The third terrace fragment at Grantchester Church represents an ancient course of the Bourn Brook that has escaped the incision seen elsewhere. At both Cardo's Pit and Grantchester Church, the MIS 7 age deposits also contain elements of an Eemian (MIS 5e) mammal fauna, suggesting a chimeric signal derived from adjacent deposits.

Eemian and early Weichselian (MIS 5a-e) fluvial (Cam Valley Formation) deposits are represented by silts (Histon Road Member) overlying the bone-rich gravelly diamicton (Impington Village Member) at Cardo's Pit, Barrington village, belonging to the third terrace of the BGS. At Abington Hall, the third terrace has been incised so that the early Eemian deposits there appear beneath the second terrace (Sidgwick Avenue Member). Middle Weichselian (MIS 4) fluvial deposits are represented by silt lenses within gravel (Arbury Member) at Trumpington village, beneath the third terrace.

Fragments of the third terrace extend from Trumpington village up each of the main river valleys (Rhee, Cam and Granta), and are also present in the valley of the Bourn Brook at Trumpington. The third terrace broadly comprises a tripartite sequence of basal gravel (Impington Village Member) overlain by silts (Histon Road Member) and capped by an upper gravel (Arbury Member). This package of sediments potentially spans the late Saalian (MIS 7) through to the early Weichselian. However, it seems clear that closely juxtaposed MIS 7 and MIS 5a-e deposits are present beneath the third terrace, but cannot be successfully differentiated using the stratigraphic information from borehole records alone. This demonstrates the problem with relying entirely upon a system of numbered terraces (the morphostratigraphic paradigm) to identify the likely age of fluvial deposits. 
Table 1. Sites and deposits of the Middle Cam valley described in the text arranged in chronostratigraphic order.

\begin{tabular}{|c|c|c|c|c|c|}
\hline Climatostratigraphic Stage & $\begin{array}{l}\text { Marine Isotope } \\
\text { Stage }\end{array}$ & Site Name & Deposit & Member (Formation) & $\begin{array}{c}\text { Geological } \\
\text { Section }\end{array}$ \\
\hline Holocene & MIS 1 & Hauxton Meadow & Silty clay and peat & Jesus Green Member (CVF) & 9 \\
\hline Holocene & MIS 1 & Barrington Dry Valley & Clay with gravel & cf. Jesus Green Member (CVF) & 5 \\
\hline Late Weichselian & MIS 2 & Barrington Dry Valley & Pellet chalk & cf. Midsummer Common Member (CVF) & 5 \\
\hline Late Weichselian & MIS 2 & Babraham Road & Lake deposit & cf. Midsummer Common Member (CVF) & 7 \\
\hline Early Weichselian & MIS 4 & Trumpington village & Silt within gravel & Arbury Member (CVF) & 7 \\
\hline Eemian/Early Weichselian & MIS 5a-e & Cardo's Pit, Barrington village & Silt overlying gravel & Histon Road Member (CVF) & 1 \\
\hline Eemian & MIS 5e & Cardo's Pit, Barrington village & Gravelly diamicton & Impington Village Member (CVF) & 1 \\
\hline Eemian & MIS 5e & Abington Hall & Silts beneath gravel & Histon Road Member (CVF) & 4 \\
\hline Saalian complex & MIS 7 & Grantchester Church & Silts beneath gravel & Histon Road Member (CVF) & 8 \\
\hline Saalian complex & MIS 7 & Cardo's Pit, Barrington village & Silt within basal gravel & Impington Village Member (CVF) & 1 \\
\hline Elsterian & MIS 12 & Whittlesford Station & Glaciolacustrine silt & Wicken Bonhunt Member (LF) & 3 \\
\hline Elsterian & MIS 12 & Whittlesford Station & Glacial Gravel & Observatory Member (LF) & 3 \\
\hline Elsterian & MIS 12 & Whittlesford Station & Glacial Diamicton & Barrington Works Member (LF) & 3 \\
\hline Elsterian & MIS 12 & Clarke's Hill & Glacial Gravel & Observatory Member (LF) & 6 \\
\hline Elsterian & MIS 12 & Barrington Works (Chapel Hill) & Glacial Diamicton & Barrington Work Member (LF) & 5 \\
\hline
\end{tabular}


Middle Weichselian (MIS 3) fluvial deposits are represented by second terrace gravels (Sidgwick Avenue Member) throughout the Middle Cam valley. The second terrace extends from the valley of Hobson's Brook along each of the river valleys. It is present in the Bourn Brook valley, but is only fragmentary along the current course of the River Cam at Grantchester.

Late Weichselian (MIS 2) river gravels often occur as a poorly developed first terrace at the edge of the Holocene floodplain (Barnwell Station Member) and as a basal in-filling of the channel form beneath the floodplain itself (Midsummer Common Member). The late-Glacial avulsion of the River Cam to the west of Trumpington created a deep channel incised to ca. $0 \mathrm{~m}$ O.D. at Byron's Pool. The pellet chalk from the dry valleys at Barrington Works (Chapel Hill) and the lake deposit from Babraham Road are also late-Weichselian in age.

Holocene deposits are represented by the peats and silts beneath every floodplain, and are exemplified by the sequence at Hauxton Meadow, which gives a view of the changing Holocene palaeoenvironments of the River Cam. The clay with gravel from the dry valleys at Barrington Works (Chapel Hill) also belongs to the early Holocene.

It is clear that the Middle Cam has been sculpted by a distinctive combination of bedrock geology, Elsterian glaciation, fluvial activity, and Weichselian periglaciation. The area has a diverse landscape history that clearly deserves recognition for its geological interest. The Middle Cam valley links the tunnel valley-dominated landscape of the Upper Cam to the south, through Cambridge City to the Lower Cam valley to the north, where the river enters the Fenland Basin. There are clear similarities between the fluvial sequences preserved in the Middle Cam and other Fenland rivers such as the River Great Ouse and River Nene, which also connect to The Wash and the southern North Sea [4]. Any differences between these sequences serve to illustrate local circumstances of bedrock, landscape, and glacial history.

Author Contributions: K.L. edited the manuscript and carried out fieldwork and laboratory work on the Hauxton Meadow deposits as part of her MPhil studies at Cambridge. S.B. was responsible for all other parts of the research, except where the assistance of others has been explicitly stated.

Funding: This research received no external funding.

Acknowledgments: The authors would like to thank C. P. Hart, R. C. Preece, C. Turner, A. Dixon, B. Briant and M. Bateman for their help with analyses.

Conflicts of Interest: The authors declare no conflict of interest.

\section{References}

1. Boreham, S.; Rolfe, C.J. Holocene, Weichselian Late-glacial earlier Pleistocene deposits of the upper Cam valley at the Hinxton Genome Campus, Cambridgeshire, UK. Neth. J. Geosci. 2009, 88, 117-125. [CrossRef]

2. Boreham, S. The Geology of the Wicken Vision Area, lower Cam valley, Cambridgeshire, UK. Neth. J. Geosci. 2013, 92, 47-59. [CrossRef]

3. Boreham, S. The Pleistocene Stratigraphy and Palaeoenvironments of the Cambridge District. Ph.D. Thesis, Open University, Milton Keynes, UK, 2002.

4. Boreham, S.; White, T.S.; Bridgland, D.R.; Howard, A.J.; White, M.J. The Quaternary history of the Wash fluvial network, UK. Proc. Geol. Assoc. 2010, 121, 393-409. [CrossRef]

5. Worssam, B.C.; Taylor, J.H. Geology of the Country around Cambridge; Memoir of the Geological Survey, HMSO: London, UK.

6. Moorlock, B.S.P.; Boreham, S.; Woods, M.A.; Sumbler, M.G. Geology of the Saffron Walden-A Brief Explanation of the Geological Map; 1:50 000 Sheet 205 Saffron Walden (England and Wales); Sheet Explanation of the British Geological Survey: Keyworth, UK, 2003.

7. Matthews, A.M.; Harvey, B.I. Records of Wells in the Area of New Series One-Inch (Geological) Huntingdon (187) and Cambridge (188) Sheets; Water Supply Papers Geological Survey, GB; HMSO: London, UK, 1965.

8. Forbes, C.L. Geology and Groundwater. In the Cambridge Region 1965; Steers, J.A., Ed.; British Association for the Advancement of Science: London, UK, 1965. 
9. Bowen, D.Q. A revised correlation of Quaternary deposits in the British Isles; Geological Society Special Report No. 23; Geological Society of London: London, UK, 1999; p. 174.

10. Dixon, A.J. The sand and gravel resources of the country around Cottenham, Cambridgeshire; Mineral Assessment Report 53; Institute of Geological Sciences, HMSO: London, UK, 1980.

11. Clayton, A.R. The sand and gravel resources of the country between Ely and Cambridge, Cambridgeshire; Mineral Assessment Report 73; Institute of Geological Sciences, HMSO: London, UK, 1981.

12. British Geological Survey. Saffron Walden Sheet. England and Wales Sheet 205 Solid and Drift Geology. 1:50 000; British Geological Survey: London, UK, 2003.

13. Lambert, C.A.; Pearson, R.G.; Sparks, B.W. A flora and fauna from late Pleistocene deposits at Sidgwick Avenue, Cambridge. Proc. Linn. Soc. Lond. 1962, 174, 13-30. [CrossRef]

14. Godwin, H.; Willis, E.H. Cambridge University natural radiocarbon measurements VI. Radiocarbon 1964, 6 , 116-137. [CrossRef]

15. Miall, A.D. A review of the braided river depositional environment. Earth Sci. Rev. 1977, 13, 1-62. [CrossRef]

16. Postma, G. Depositional architecture and facies of river and fan deltas: A synthesis. Spec. Publs. Int. Ass. Sediment 1990, 10, 13-27.

17. Bennett, K.D.; Fossitt, J.A.; Sharp, M.J.; Switsur, V.R. Holocene vegetational and environmental history at Loch Lang, South Uist, Western Isles, Scotland. New Phytol. 1990, 114, 281-298. [CrossRef]

18. Faegri, K.; Iversen, J. Textbook of Pollen Analysis; Blackwell Scientific: London, UK, 1989.

19. Moore, P.D.; Webb, J.A.; Collinson, M.E. Pollen Analysis, 2nd ed.; Blackwell: London, UK, 1991.

20. Kerney, M.P. Atlas of the Non-Marine Mollusca of the British Isles; Graphic Art Ltd.: Cambridge, UK, 1976.

21. Lucht, W.H. Die Kafer Mitteleuropas: Katalog; Geocke Evers: Krefeld, Germany, 1987.

22. Bateman, M.D.; Catt, J.A. An absolute chronology for the raised beach deposits at Sewerby, East Yorkshire, U.K. J. Quat. Sci. 1996, 11, 389-395. [CrossRef]

23. Miller, G.H.; Brigham-Grette, J. Amino acid geochronology: Resolution and precision in carbonate fossils. Quat. Int. 1989, 1, 111-128. [CrossRef]

24. Stuiver, M.; Polach, H. Discussion: Reporting of $14 \mathrm{C}$ data. Radiocarbon 1977, 19, 355-363. [CrossRef]

25. Fisher, O. On a Mammaliferous Deposit at Barrington near Cambridge. Q. J. Geol. Soc. 1879, 35, 670-677. [CrossRef]

26. Hughes, M. On the mollusca of the Pleistocene gravels in the neighbourhood of Cambridge. Geol. Mag. 1888, 5, 193-207. [CrossRef]

27. Hughes, M. The Gravels of East Anglia; Cambridge University Press: Cambridge, UK, 1916.

28. Gibbard, P.L.; Stuart, A.J. Flora and vertebrate fauna of the Barrington Beds. Geol. Mag. 1975, 99, 97-118. [CrossRef]

29. Turner, C. Einfluß großer Mammalier auf die interglaziale Vegetation. Quärtarpaläontologie 1975, 1, 13-19.

30. Kennard, A.S.; Woodward, B.B. The post-Pliocene non-marine Mollusca of the East of England. Proc. Geol. Assoc. 1922, 33, 104-142. [CrossRef]

31. Sparks, B.W. Notes on some Pleistocene sections at Barrington, Cambridgeshire. Geol. Mag. 1952, 89, $163-174$. [CrossRef]

32. Keen, D.H. Significance of the record provided by Pleistocene fluvial deposits and their included mollusc faunas for palaeoenvironmental reconstruction and stratigraphy: Case studies from the English Midlands. Palaeogeogr. Palaeoclimatol. Palaeoecol. 1990, 80, 25-34. [CrossRef]

33. Preece, R.C. Mollusca from interglacial sediments at three critical sites in the Lower Thames. In The Quaternary of the Lower Reaches of the Thames; Bridgland, D.R., Allen, P., Haggart, B.A., Eds.; Field Guide; Quaternary Research Association: London, UK, 1995.

34. Stuart, A.J. Pleistocene Vertebrates of the British Isles; Longmans: London, UK, 1982.

35. Sutcliffe, A.J. Insularity of the British Isles 250000-300000 years ago: The mammalian, including human evidence. In Island Britain: A Quaternary Perspective; Preece, R.C., Ed.; Special Publication No. 96; Geological Society of London: London, UK, 1995; pp. 127-140.

36. Bridgland, D.R.; Schreve, D.C. River terrace formation in synchrony with long-term climatic fluctuation: Examples from southern Britain. In River Basin Sediment Systems: Archives of Environmental Change; Maddy, D., Macklin, M., Woodward, J., Eds.; Balkema: Rotterdam, The Netherlands, 2001; pp. 229-248.

37. Gao, C. Sedimentology and Stratigraphy of the River Great Ouse, Southern England. Unpublished Ph.D. Thesis, Clare College, University of Cambridge, Cambridge, UK, 1997. 
38. Gao, C.; Boreham, S. Ipswichian (Eemian) floodplain deposits and terrace stratigraphy in the lower Great Ouse and Cam valleys, southern England, UK. Boreas 2011, 40, 303-319. [CrossRef]

39. Norris, G. Some glacial deposits and their relationship to the Hippopotamus-bearing beds at Barrington, Cambridgeshire. Geol. Mag. 1962, 99, 97-118. [CrossRef]

40. White, H.J.O. The geology of the country near Saffron Walden. In Memoir of the Geological Survey; HMSO: London, UK, 1932.

41. Coope, G.R. Middle Devensian (Weichselian) coleopteran assemblages from Earith, Cambridgeshire (UK) and their bearing on the interpretation of 'Full glacial' floras and faunas. J. Quat. Sci. 2000, 15, 779-788. [CrossRef]

42. Hoare, P.G.; Connell, E.R. The chalky till at Barrington, near Cambridge, and its connection with other Quaternary deposits in southern Cambridgeshire and adjoining areas. Geol. Mag. 1981, 118, 463-476. [CrossRef]

43. Marr, J.E. The Pleistocene deposits of the lower part of the Great Ouse basin. Q. J. Geol. Soc. 1926, 82, 101-143. [CrossRef]

44. Sparks, B.W. A note on the Pleistocene deposit at Grantchester, Cambridgeshire. Geol. Mag. 1964, 94, $194-200$. [CrossRef]

45. British Geological Survey. Cambridge Sheet. England and Wales Sheet 188 Solid and Drift Geology. 1 50,000; British Geological Survey: London, UK, 1981.

46. Marr, J.E. The Pleistocene deposits around Cambridge. Q. J. Geol. Soc. 1920, 75, 204-244. [CrossRef]

(C) 2019 by the authors. Licensee MDPI, Basel, Switzerland. This article is an open access article distributed under the terms and conditions of the Creative Commons Attribution (CC BY) license (http://creativecommons.org/licenses/by/4.0/). 